Keywords: Saltstone

Performance Assessment

Retention: Permanent

\title{
Operational and Compositional Factors that Affect the Performance Properties of ARP/MCU Saltstone Grout
}

M.M. Reigel

T.B. Edwards

B.R. Pickenheim

February 2012

Savannah River National Laboratory Savannah River Nuclear Solutions Aiken, SC 29808

Prepared for the U.S. Department of Energy under contract number DE-AC09-08SR22470. 
SRNL-STI-2011-00665

Revision 0

\section{DISCLAIMER}

This work was prepared under an agreement with and funded by the U.S. Government. Neither the U.S. Government or its employees, nor any of its contractors, subcontractors or their employees, makes any express or implied:

1. warranty or assumes any legal liability for the accuracy, completeness, or for the use or results of such use of any information, product, or process disclosed; or

2. representation that such use or results of such use would not infringe privately owned rights; or

3. endorsement or recommendation of any specifically identified commercial product, process, or service.

Any views and opinions of authors expressed in this work do not necessarily state or reflect those of the United States Government, or its contractors, or subcontractors.

\section{Printed in the United States of America}

Prepared for

U.S. Department of Energy 


\section{REVIEWS AND APPROVALS}

AUTHORS:

M.M. Reigel, Engineering Process Development

Date

T.B. Edwards, Applied Computational Engineering \& Statistics

Date

B.R. Pickenheim, Engineering Process Development

Date

TECHNICAL REVIEW:

A.D. Cozzi, Engineering Process Development

Date

APPROVAL:

A.B. Barnes, Manager

Date

Engineering Process Development

S.L. Marra, Manager

Date

Environmental \& Chemical Process Technology Research Programs

K.H. Rosenberger, Manager

Date

Closure \& Disposal Assessment 


\section{EXECUTIVE SUMMARY}

The Saltstone Production Facility mixes salt solution from Tank $50 \mathrm{H}$ with premix of $10 \%$ cement, $45 \%$ fly ash, and $45 \%$ slag to produce fresh (uncured) saltstone that is transferred to the Saltstone Disposal Facility vaults. The saltstone formulation (mix design) must produce a grout waste form that meets both placement and performance properties. In previous simulated saltstone studies, multiple compositional factors were identified that drive the performance properties of saltstone made from the projected Actinide Removal Process/Modular Caustic Side Solvent Extraction Unit (ARP/MCU) decontaminated salt solution (DSS). This salt solution composition was chosen for this study since it is the primary feed into Tank $50 \mathrm{H}$. The primary performance property investigated was hydraulic conductivity since it is a variable input property to the Saltstone Performance Assessment (PA). In addition, the porosity, also referred to as void structure, is another variable that impacts the PA response. In addition, Young's modulus and cured density are other performance properties analyzed in this report that are direct inputs into the PA.

A statistically designed set of mixes was developed to determine key process and compositional factors that affect the performance properties of saltstone. A total of 27 mixes were batched and tested. There are eight baseline mixes that contain high and low concentrations of aluminate, varying water to premix (w/p) ratios, and varying fly ash content in the premix. Each of the eight mixes was cured at 20,40 , and $60{ }^{\circ} \mathrm{C}$. Three additional reference mixes were batched at the beginning, middle and end of testing to measure reproducibility.

The fresh properties of the grout mixes were measured to ensure the product can be processed through the facility and sent to the vault. The mixes had no bleed after one day except for mixes 18 and 24. The surface of these two samples was still wet after one day but there was not enough bleed to measure. In addition to no bleed, all of the grouts gelled within 60 minutes, which is within the processing guidelines used to support the saltstone facility.

The results of varying the operational and compositional factors over the ranges investigated on the performance properties of saltstone are:

- The Young's modulus is inversely affected by the curing temperature of the grout.

- The aluminate content of the salt solution increases the Young's modulus of the saltstone for samples cured at 20 and $40{ }^{\circ} \mathrm{C}$.

- All grouts cured at $60^{\circ} \mathrm{C}$ have low Young's moduli compared to the same grout cured at room temperature.

- Changing the composition (aluminate molarity, fly ash concentration, and w/p) did not improve the performance properties of saltstone cured at $60^{\circ} \mathrm{C}$.

- The fly ash content in the premix had no discernible effect on the Young’s modulus.

- The water to premix ratio does not affect the Young's modulus.

- Grouts made with the high aluminate salt solution have lower hydraulic conductivities than those made with the low aluminate simulant.

- Higher curing temperatures result in higher values of hydraulic conductivity.

- In general, increasing the water to premix ratio and the fly ash content will increase the hydraulic conductivity, specifically for grouts cured at low temperatures.

- The porosity and cured density of the saltstone are primarily a factor of the water to premix ratio of the grout formulation.

The correlation between hydraulic conductivity and Young's modulus investigated in previous studies was evaluated further in this report. The current data, as well as data from previous studies, 
were fitted by a second degree polynomial function with a $77.1 \%$ R-squared value. This model can be used to estimate the hydraulic conductivity of a sample based on its Young's modulus for a limited range (E values up to $7 \mathrm{GPa}$ ). More data points would have to be included to further define the relationship between these performance properties for high Young's moduli and low hydraulic conductivities. Based on current and past data, Young's modulus is not a viable method to estimate the hydraulic conductivity of saltstone.

Saltstone has a complicated microstructure that is affected by the composition of the salt solution, the dry feed mixture composition, and the conditions under which it cures. The performance properties investigated are interrelated, which can make it difficult to determine individual relationships between various factors. Porosity has a significant impact on both the Young's modulus and the hydraulic conductivity of the samples. Although the cured density is a straightforward measurement, it is not a significant performance property that needs further investigation. The porosity measurement provides similar and more meaningful data in relation to other performance properties.

Based on the results of this study, the aluminate content of the salt solution does have an effect on the Young's modulus and the hydraulic conductivity and its effects should continue to be investigated. However, a new projection of aluminate content in the salt solution waste should be used since projections can change with revisions of the planning document. The variability of fly ash in the premix did not prove to be a significant factor that affects the performance properties of saltstone.

The water to premix ratio has a significant effect on the performance properties of interest and the effects of varying this factor need further investigation. It is recommended that smaller incremental ranges of $\mathrm{w} / \mathrm{p}$ be investigated while still allowing for a wide range of $\mathrm{w} / \mathrm{p}$ ratios in order to provide data that are more relevant to the saltstone being placed in the vaults.

An additional part of this study includes curing selected samples under temperatures recorded in the SDF. The cure temperatures used in this study are representative of selected temperatures measured in the SDF vaults and, it is obvious that curing saltstone at high temperatures has a negative effect on the performance properties. However, the grout in the SDF vaults does not cure at a single temperature, rather it is exposed to a variable and gradually increasing temperature profile after it is placed. Some samples were cured under such temperature profiles and tested to determine the effect of a lower starting curing temperature followed by a higher ending temperature. After 10 days of curing, samples that reached a maximum of $55{ }^{\circ} \mathrm{C}$ outperformed samples that were cured at $80{ }^{\circ} \mathrm{C}$ in terms of Young's modulus. However, drying of the samples that were cured at higher temperatures is evident. It is recommended that in addition to curing under vault temperature profiles, samples be cured at high relative humidities in order to maintain saturated grout. It is unclear if the deleterious effects of curing at high temperatures is solely due to the drying of the samples or if there are other effects of curing at elevated temperatures. Curing future samples at various relative humidities will provide further insight into the performance properties of saltstone. 


\section{TABLE OF CONTENTS}

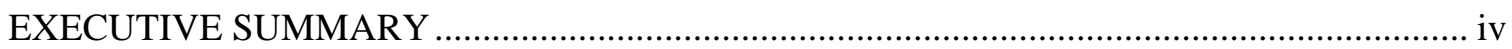

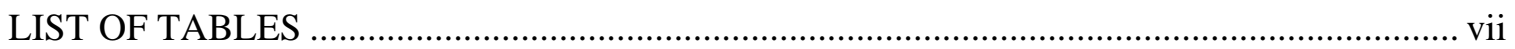

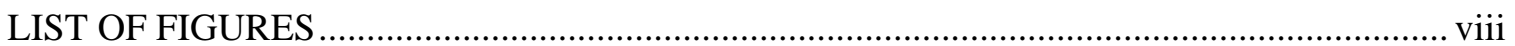

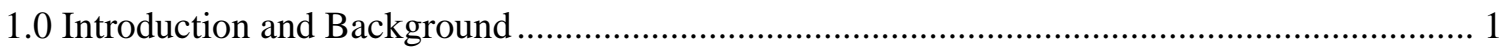

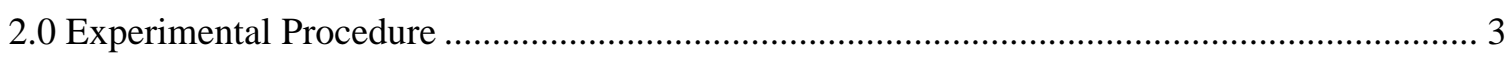

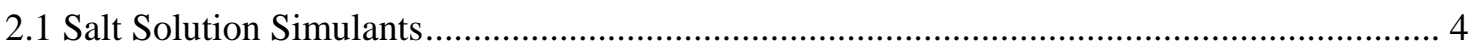

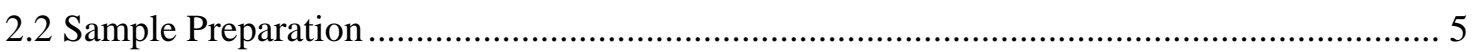

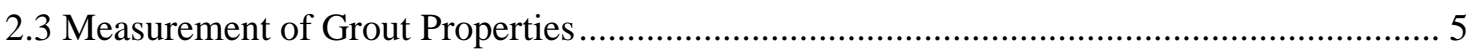

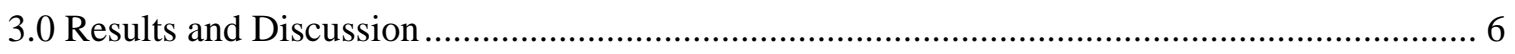

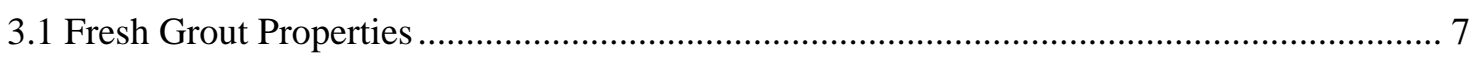

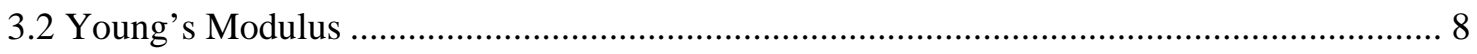

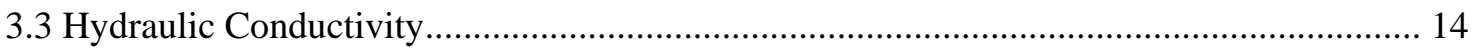

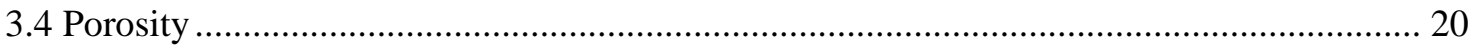

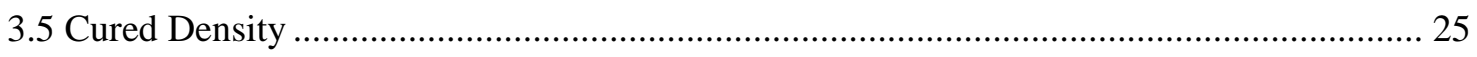

3.6 Correlation between Dynamic Young's Modulus and Hydraulic Conductivity .................. 30

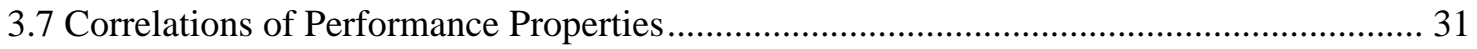

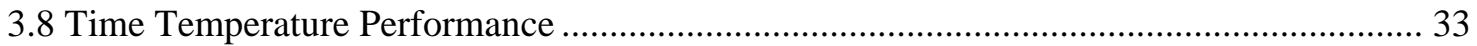

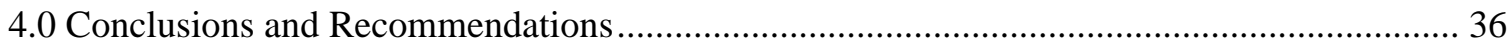

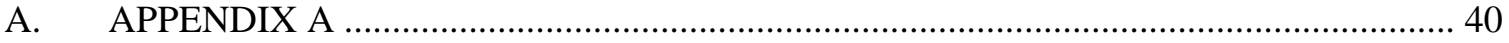




\section{LIST OF TABLES}

Table 2-1. Experimental design for Saltstone mixes tested........................................................... 3

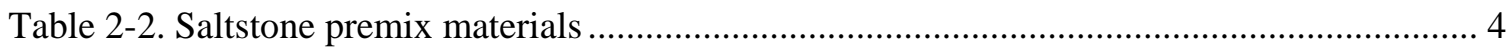

Table 2-3. Batch sheets for ARP/MCU salt solution simulants ................................................... 5

Table 3-1. Fresh grout properties for the 27 grout mixes. ......................................................... 7

Table 3-2. Young's modulus values from lowest to highest and the associated operational and

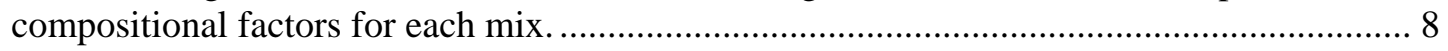

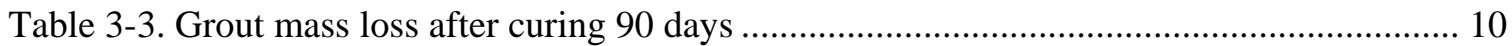

Table 3-4. Summary of fit for the response of Young's modulus values compared to the predicted

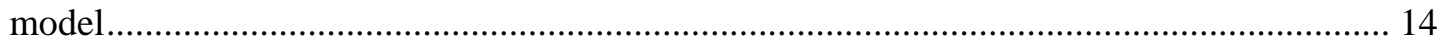

Table 3-5. Hydraulic conductivity values listed from highest to lowest and the associated operational and compositional factors for each mix. ....................................................... 15

Table 3-6. Summary of fit for the response of common logarithm of hydraulic conductivity values

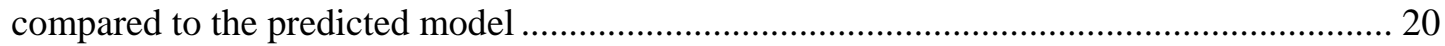

Table 3-7. Porosity values listed from lowest to highest and the associated operational and

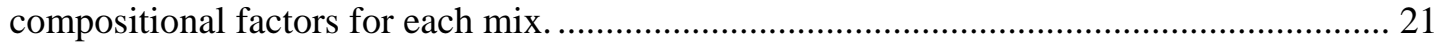

Table 3-8. Summary of fit for the response of porosity values compared to the predicted model 25

Table 3-9. Cured density values listed from lowest to highest and the associated operational and

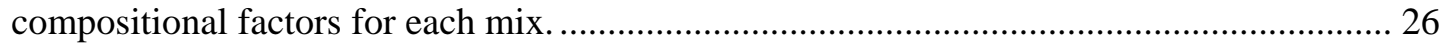

Table 3-10. Summary of fit for the response of cured density values compared to the predicted

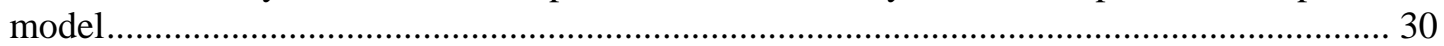

Table 3-11. Multivariate correlations between Saltstone performance properties ........................ 31

Table 3-12 Mass loss in Time-Temperature samples ................................................................... 35

Table A-1. Batch formulations for samples from report SRNL-STI-2009-00419....................... 41

Table A-2. Performance properties of mixes batched in SRNL-STI-2009-00419 ........................ 41 


\section{LIST OF FIGURES}

Figure 2-1. Time temperature curing for samples cured under actual vault temperatures .............. 4

Figure 3-1. Young's modulus as a function of cure temperature for all grout mixes...................... 9

Figure 3-2. Young's modulus as a function of w/p for all grouts................................................ 11

Figure 3-3. Variability chart for Young's modulus as a function of operational and compositional

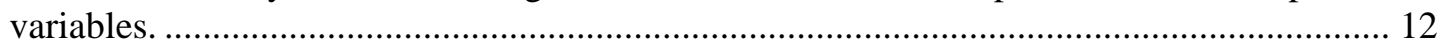

Figure 3-4. Response of Young's modulus due to operational and compositional variables, (a) actual by predicted and (b) residual by predicted. ............................................................. 13

Figure 3-5. Hydraulic conductivity as a function of cure temperature for 27 grout mixes. .......... 16

Figure 3-6. Hydraulic Conductivity as a function of w/p for all mixes..................................... 17

Figure 3-7. Variability chart for hydraulic conductivity as a function of operational and

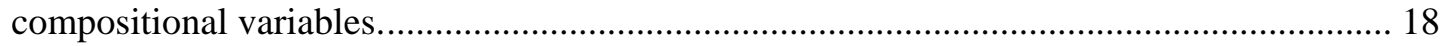

Figure 3-8. Response of hydraulic conductivity due to operational and compositional variables, (a) actual by predicted and (b) residual by predicted............................................................. 19

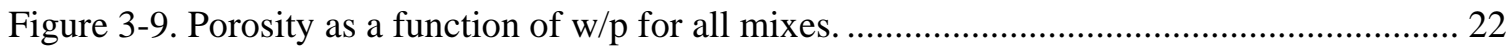

Figure 3-10. Variability chart for porosity as a function of operational and compositional variables.

Figure 3-11. Response of porosity due to operational and compositional variables, (a) actual by predicted and (b) residual by predicted.

Figure 3-12. Cured density as a function of w/p for all mixes.

Figure 3-13. Variability chart for cured density as a function of operational and compositional variables.

Figure 3-14. Response of cured density due to operational and compositional variables, (a) actual by predicted and (b) residual by predicted.

Figure 3-15. $\log _{10}$ of hydraulic conductivity as a function of Young's modulus showing a second

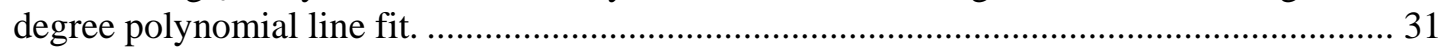

Figure 3-16. Scatter plot matrix showing the correlation between performance properties.......... 32

Figure 3-17. Young's modulus as a function of curing time at varying temperature profiles....... 33

Figure 3-18. SEM image of grout cured for 24 days at high temperature 34 


\section{LIST OF ABBREVIATIONS}

$\begin{array}{ll}\text { ARP } & \text { Actinide Removal Process } \\ \text { ASTM } & \text { American Society for Testing and Materials } \\ \text { BFS } & \text { Blast Furnace Slag } \\ \text { DF } & \text { Degrees of Freedom } \\ \text { DSS } & \text { Decontaminated Salt Solution } \\ \text { DSS-HT } & \text { Decontaminated Salt Solution Hold Tank } \\ \text { E } & \text { (dynamic) Young's Modulus } \\ \text { ETP } & \text { Effluent Treatment Project } \\ \text { FA } & \text { Fly Ash } \\ \text { LLW } & \text { Low Level Waste } \\ \text { MCU } & \text { Modular Caustic Side Solvent Extraction Unit } \\ \text { PA } & \text { Performance Assessment } \\ \text { PC } & \text { Portland Cement } \\ \text { RH } & \text { Relative Humidity } \\ \text { RSME } & \text { Root Mean Square Error } \\ \text { SDF } & \text { Saltstone Disposal Facility } \\ \text { SPF } & \text { Saltstone Production Facility } \\ \text { SRNL } & \text { Savannah River National Laboratory } \\ \text { w/p } & \text { Water to Premix } \\ \text { wt \% } & \text { Weight Percent }\end{array}$




\subsection{Introduction and Background}

The Saltstone Production Facility (SPF) receives low level waste (LLW) salt solution from Tank $50 \mathrm{H}$ for treatment and disposal. Tank $50 \mathrm{H}$ receives transfers from the Effluent Treatment Project (ETP), the H-Canyon General Purpose Evaporator, and the Actinide Removal Process/Modular Caustic Side Solvent Extraction Unit (ARP/MCU) Decontaminated Salt Solution Hold Tank (DSS-HT). At the SPF, the LLW is mixed with premix (a cementitious mixture of portland cement (PC), blast furnace slag (BFS) and Class F fly ash (FA)) in a Readco mixer to produce fresh (uncured) saltstone that is transferred to the Saltstone Disposal Facility (SDF) vaults. ${ }^{1}$ The saltstone formulation (mix design) must produce a grout waste form that meets both placement and performance properties. In previous simulated saltstone studies, ${ }^{1,2}$ multiple compositional factors were identified that drive the performance properties of saltstone made from the projected ARP/MCU salt solution. This composition was selected as salt solution simulant since ARP/MCU is the primary influent into Tank $50 \mathrm{H}$. The primary performance property investigated was hydraulic conductivity since it is a variable input property to the saltstone Performance Assessment (PA) transport model. In addition, the porosity, also referred to as void structure, is another variable that impacts the PA response. ${ }^{3}$ In addition, Young's modulus and cured density are other performance properties analyzed in this report; however they are indicators of the performance of saltstone and not direct inputs into the PA.

The data from previous studies showed that the largest impact on the performance properties of saltstone was due to curing temperature, followed by aluminate concentration in the salt solution, water to premix ratio and premix composition. ${ }^{1,2}$ However, due to the scope of the previous studies, only a few mixes were cured and analyzed at higher temperatures. The samples cured at $60{ }^{\circ} \mathrm{C}$ had an increased hydraulic conductivity of approximately 600 times that of the sample cured at room temperature. ${ }^{2}$ The hydration reactions initiated during the mixing of the premix and salt solution continue during the curing period in the vaults to produce the hardened waste form product. The heat generated from exothermic hydration reactions results in a temperature increase in the vaults that depends on the composition of the decontaminated salt solution being dispositioned, the grout formulation (mix design) and the pour frequency and volume. This heat generation is a contributing factor to the temperature increase in the vaults that leads to an increased cure temperature for the grout.

This report will further investigate the impact of curing temperature on saltstone performance properties (hydraulic conductivity, Young's modulus, porosity, etc.) over a range of aluminate concentration, water to premix (w/p) ratio and weight percent fly ash in the premix processed at the SPF. The three curing temperatures selected for this study were chosen to provide data at fixed cure temperatures that represent measured temperatures in the SDF vaults. This does not represent the conditions in the vault where the temperature of the saltstone is continually changing with time. For example, it may take several days for the saltstone to reach $60{ }^{\circ} \mathrm{C}$ at a given elevation. Previous results demonstrated that the rates at which a selected curing temperature is reached affect the performance properties. ${ }^{4}$ The approach taken in this task, a rapid increase to the curing temperature, may be conservative with respect to decreased performance. Nevertheless, the data will provide a basis from which to determine the impact of curing temperature on saltstone performance as a function of key variables. ${ }^{5}$ A statistical evaluation ${ }^{6}$ of the results for these mixes will be performed to provide the range, and associated uncertainties, of hydraulic conductivity and other properties over this factor space.

The dynamic Young's modulus was originally investigated as a performance property indicator due to the limited availability of equipment to measure the hydraulic conductivity of saltstone samples. The results from these studies ${ }^{4,7}$ indicate a relationship may exist between Young's 
Revision 0

modulus and hydraulic conductivity. The results from previous studies will be combined with the results from this study and statistically assessed. The hydraulic conductivity and dynamic Young's modulus values will be combined to determine whether a correlation can be established for these properties and therefore dynamic Young's modulus can be used as an indicator of the performance of saltstone samples. 


\subsection{Experimental Procedure}

A statistically designed set of mixes was developed to investigate the key process and compositional factors that affect the performance properties of saltstone. There are eight baseline mixes that contain high and low values of aluminate concentration, varying w/p ratio, and varying fly ash content in the premix. Each of the eight mixes was cured at 20, 40, and $60{ }^{\circ} \mathrm{C}$. Three additional reference mixes were batched at the beginning, middle and end of testing to measure reproducibility. A total of 27 mixes were batched and tested (Table 2-1). Mix numbers 1, 14, and 27 are the reference mixes and are at the mid-points of the compositional and process factors tested. These reference mixes were run at the beginning, middle, and end of the experiment and used as an indicator of repeatability of batching and analysis methods. The batch order (run number) for the mixes was chosen at random. Throughout discussion of the results, the mix number will be used to reference the grout sample.

Table 2-1. Experimental design for saltstone mixes tested

\begin{tabular}{|c|c|c|c|c|c|}
\hline $\begin{array}{c}\text { Mix } \\
\text { Number }\end{array}$ & $\begin{array}{c}\text { Run } \\
\text { Number }\end{array}$ & $\begin{array}{c}\text { Aluminate } \\
\text { Molarity }\end{array}$ & $\mathbf{w} / \mathbf{p}$ & $\begin{array}{c}\text { Fly Ash } \\
\text { (wt \%) }\end{array}$ & $\begin{array}{c}\text { Isothermal } \\
\text { Curing } \\
\text { Temp }\left({ }^{\circ} \mathrm{C}\right) \\
\end{array}$ \\
\hline 1 & 1 & 0.165 & 0.60 & 47.5 & 40 \\
\hline 2 & 12 & 0.05 & 0.55 & 45 & 20 \\
\hline 3 & 8 & 0.05 & 0.55 & 45 & 40 \\
\hline 4 & 4 & 0.05 & 0.55 & 45 & 60 \\
\hline 5 & 13 & 0.05 & 0.65 & 45 & 20 \\
\hline 6 & 9 & 0.05 & 0.65 & 45 & 40 \\
\hline 7 & 5 & 0.05 & 0.65 & 45 & 60 \\
\hline 8 & 17 & 0.05 & 0.55 & 50 & 20 \\
\hline 9 & 19 & 0.05 & 0.55 & 50 & 40 \\
\hline 10 & 15 & 0.05 & 0.55 & 50 & 60 \\
\hline 11 & 20 & 0.05 & 0.65 & 50 & 20 \\
\hline 12 & 21 & 0.05 & 0.65 & 50 & 40 \\
\hline 13 & 25 & 0.05 & 0.65 & 50 & 60 \\
\hline 14 & 14 & 0.165 & 0.60 & 47.5 & 40 \\
\hline 15 & 10 & 0.28 & 0.55 & 45 & 20 \\
\hline 16 & 6 & 0.28 & 0.55 & 45 & 40 \\
\hline 17 & 3 & 0.28 & 0.55 & 45 & 60 \\
\hline 18 & 11 & 0.28 & 0.65 & 45 & 20 \\
\hline 19 & 7 & 0.28 & 0.65 & 45 & 40 \\
\hline 20 & 2 & 0.28 & 0.65 & 45 & 60 \\
\hline 21 & 18 & 0.28 & 0.55 & 50 & 20 \\
\hline 22 & 22 & 0.28 & 0.55 & 50 & 40 \\
\hline 23 & 24 & 0.28 & 0.55 & 50 & 60 \\
\hline 24 & 16 & 0.28 & 0.65 & 50 & 20 \\
\hline 25 & 26 & 0.28 & 0.65 & 50 & 40 \\
\hline 26 & 23 & 0.28 & 0.65 & 50 & 60 \\
\hline 27 & 27 & 0.165 & 0.60 & 47.5 & 40 \\
\hline
\end{tabular}

The nominal premix distribution used in this testing is $45 \mathrm{wt} \%$ slag, $45 \mathrm{wt} \%$ Class F fly ash that has been thermally beneficiated and $10 \mathrm{wt} \%$ portland cement. For those mixes batched using 50 
wt \% fly ash, the slag content was reduced to $40 \mathrm{wt} \%$. The cement content was held constant for the reference mixes and the slag content was decreased to accommodate the increase in fly ash. The premix materials (Table 2-2) were received in five gallon containers from the vendors during delivery of the bulk materials to the SPF. The premix materials were maintained such that the exposure to humid air and hydration was limited prior to use.

Table 2-2. Saltstone premix materials

\begin{tabular}{|c|c|c|}
\hline Material & Category & Vendor \\
\hline Portland Cement & ASTM C 150/ C 150M-11 & Holcim \\
\hline Blast Furnace Slag & ASTM C 989-10 & Holcim \\
\hline Fly Ash & ASTM C 618-08a & SEFA \\
\hline
\end{tabular}

Since curing the sample under an isothermal temperature is not completely representative of the curing profiles monitored in the saltstone vaults, an additional matrix of samples was generated to investigate the effect of curing time under different temperature profiles. These samples were all prepared with the high aluminate $(0.28 \mathrm{M})$ salt solution and the nominal premix distribution. Three w/p ratios $(0.55,0.60,0.65)$ and two temperature profiles were tested for a total of six sets of samples. The temperature profiles used are included below (Figure 2-1). Actual saltstone facility data from Cells $\mathrm{F}$ and $\mathrm{K}$ were used to generate these temperature profiles.

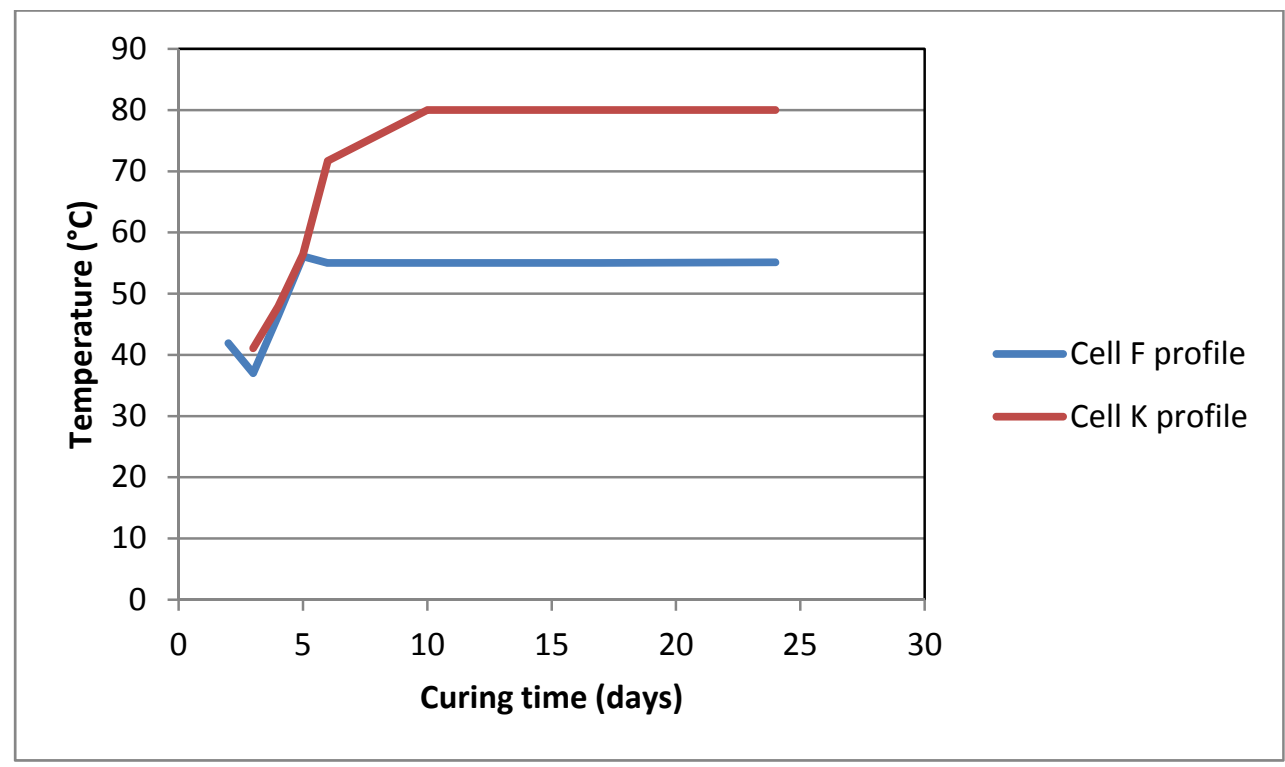

Figure 2-1. Time temperature curing for samples cured under actual vault temperatures

\subsection{Salt Solution Simulants}

Three low-level waste salt solutions were used for this study. High aluminate $(0.28 \mathrm{M})$ and low aluminate $(0.05 \mathrm{M})$ simulants were all prepared based on ARP/MCU composition projections. The composition of the ARP/MCU simulant used for the reference mixes $(1,14$ and 27$)$ has an aluminate concentration of $0.165 \mathrm{M}$ and is the mid-point of the low and high aluminate simulants.

\footnotetext{
* Data was provided by WD to SRNL in an email on April 5, 2011. Vault 4 cell F and cell K data was obtained from the database using PI.
} 
To date, the SPF processes salt solution from Tank $50 \mathrm{H}$ which has a low aluminate molarity. The high aluminate molarity salt solution is a predicted composition based on future waste stream processes feeding Tank $50 \mathrm{H}^{8}{ }^{8}$

Table 2-3. Batch sheets for ARP/MCU salt solution simulants

\begin{tabular}{|c|c|c|c|c|c|c|}
\hline \multirow{2}{*}{ Compound } & \multicolumn{2}{|c|}{ Low Aluminate } & \multicolumn{2}{|c|}{ Mid Aluminate } & \multicolumn{2}{|c|}{ High Aluminate } \\
\hline & Molarity & $\mathrm{g} / \mathrm{mol}$ & Molarity & $\mathrm{g} / \mathrm{mol}$ & Molarity & g/mol \\
\hline $50 \%$ by Weight $\mathrm{NaOH}$ & 2.000 & 40.00 & 2.460 & 40.00 & 2.920 & 40.00 \\
\hline $\mathrm{NaNO}_{3}$ & 2.210 & 84.99 & 1.865 & 84.99 & 1.520 & 84.99 \\
\hline $\mathrm{NaNO}_{2}$ & 0.550 & 68.99 & 0.550 & 68.99 & 0.550 & 68.99 \\
\hline $\mathrm{Na}_{2} \mathrm{CO}_{3}$ & 0.176 & 105.99 & 0.176 & 105.99 & 0.176 & 105.99 \\
\hline $\mathrm{Na}_{2} \mathrm{SO}_{4}$ & 0.059 & 142.04 & 0.059 & 142.04 & 0.059 & 142.04 \\
\hline Aluminum Nitrate $\left(9 \mathrm{H}_{2} \mathrm{O}\right)$ & 0.050 & 375.13 & 0.165 & 375.13 & 0.280 & 375.13 \\
\hline Sodium Phosphate $\left(12 \mathrm{H}_{2} \mathrm{O}\right)$ & 0.012 & 380.12 & 0.012 & 380.12 & 0.012 & 380.12 \\
\hline Total Salt mass (g) & \multicolumn{2}{|c|}{345.47} & \multicolumn{2}{|c|}{359.06} & \multicolumn{2}{|c|}{372.65} \\
\hline Total Na Molarity & \multicolumn{2}{|c|}{5.27} & \multicolumn{2}{|c|}{5.38} & \multicolumn{2}{|c|}{5.50} \\
\hline
\end{tabular}

\subsection{Sample Preparation}

The salt solution and premix materials were mixed for approximately three minutes using a paddle blade mixer. The mixing was paused for approximately five seconds after 30 seconds of mixing to allow entrained air to escape from the grout. Each grout mix (Table 2-1) was batched in duplicate 3200 gram batches to facilitate complete mixing and ease of handling.

For samples cured isothermally, each mix was cured for a total of 90 days before being analyzed. For the first 28 days of the cure cycle, the sample was cured at ambient temperature on a bench top (nominally $20^{\circ} \mathrm{C}$ ) or in ovens set at either 40 or $60{ }^{\circ} \mathrm{C}$. After 28 days, the samples were removed from the oven and cured at ambient temperature for the remaining 62 days. The samples were weighed after being poured into sample cylinders and then again after curing for 90 days.

\subsection{Measurement of Grout Properties}

Fresh properties were measured after the grout had mixed for the designated three minutes. These properties include: density, yield stress, plastic viscosity, bleed water volume, gel time and set time $^{9}$. Rheological properties were measured using a Haake M5/RV30 rotoviscometer. The flow curves for the mixes were fitted to the Bingham Plastic rheological model to determine the yield stress $(\mathrm{Pa})$ and plastic viscosity $(\mathrm{cP})$. The bleed water volume was measured on duplicate samples of fresh grout placed in sealed cylinders and left untouched for 24 hours.

For gel time, fresh grout was poured into a series of cylinders and left undisturbed. Every five minutes, the grout was poured from a cylinder into an empty container. This was repeated until the fresh grout had developed sufficient structure such that it did not flow as a result of its own mass. The time at which the grout did not flow from the cylinder was designated as the gel time. A Vicat needle was used to determine the final set times ${ }^{9}$ twice daily.

The dynamic Young's Modulus (E) was measured according to ASTM standard C $215^{10}$ using an E-Meter Mk II Resonant Frequency Tester by James Instruments Inc. The method involves a 
longitudinal impact on the end of a 3 x 6 inch cylinder of cast and cured paste, detection of the sound waves produced at the opposite end of the cylinder, and measurement of the fundamental resonance frequency of the cylinder through a fast Fourier transform of the time domain signal. Using this resonance frequency and the independently measured mass and dimensions of the cylinder, the dynamic Young's modulus was calculated. ${ }^{10}$ The dynamic method for measuring Young's modulus provides a greater value than static methods. ${ }^{11}$ All references to Young's modulus in this report are referring to the dynamic method.

The porosity was determined by the mass loss ${ }^{12}$ upon heating samples ( 1.5 to 2 grams) to $105{ }^{\circ} \mathrm{C}$ using a Mettler Toledo HR83 Moisture Analyzer after the sample had cured for 90 days. This instrument measures mass loss as a function of time until no further mass loss is observed. The typical time for measurement is on the order of 30 minutes but can be up to one hour if the cured grout is not broken into smaller pieces. The grout pieces that were used in the measurement of porosity were taken from the center of the cylinder by breaking the cylinder and removing pieces from near the center region.

The Young's modulus, ${ }^{10}$ moisture retention, ${ }^{13}$ porosity, and density of the cured samples were tested at SRNL. In addition, the saturated hydraulic conductivity, ${ }^{14}$ moisture retention, dry bulk density, and porosity were measured by an offsite laboratory ${ }^{*}$ after they had cured for 90 days at SRNL. The saturated hydraulic conductivity of the saltstone samples was determined by ASTM D 5084 method F, the constant-volume falling head using a flexible wall permeameter. ${ }^{14}$ The fluid used for testing was the low aluminate salt solution. This was used to avoid interactions of the test fluid and the sample during testing. Saturated hydraulic conductivity is a function of the porous medium and the properties of the test fluid as described by Darcy's law (Equation 1). ${ }^{15}$

$$
\frac{d q}{d t}=K \frac{\Delta H A}{L \mu}
$$

Where $d q / d t$ is the rate of fluid flow, $\mu$ is the viscosity of the fluid, $\Delta H$ is the pressure gradient, $A$ is the surface area, and $L$ is the thickness of the solid. Additional details of the testing and calculations for moisture retention and hydraulic conductivity results provided by Mactec are documented in previous reports. ${ }^{1,2,13}$

\subsection{Results and Discussion}

The results presented in this report investigate the effect of cure temperature on the performance properties (hydraulic conductivity, Young's modulus, etc.) as well as the effects of other compositional factors on the cured properties of saltstone. The correlation between hydraulic conductivity and Young's modulus investigated in previous studies ${ }^{16,17}$ is evaluated further in this report. In addition, the results from the study on saltstone performance properties prior to this study $^{2}$ (APPENDIX A) are included in the statistical analysis in order to further define the key compositional and operational factors that affect the performance properties of saltstone. It should be noted that some of the mixes in the previous study contain organics and admixtures that were not included in the current study.

Since saltstone has no aggregate, it can be considered a cementitious paste rather than a concrete for determining the phenomena that control its performance properties. Therefore, the relationships referenced from literature will be to cement or grout pastes rather than traditional concretes.

\footnotetext{
* AMEC E\&I (formerly Mactec), 396 Plasters Ave, Atlanta, GA, 30324
} 


\subsection{Fresh Grout Properties}

The fresh properties of the grout mixes are important to ensure the product can be processed through the facility and transferred to the SDF vault. In the vault, the grout should be formulated such that it sets within three days and produces less than three volume percent of bleed water. The gel time of the fresh grout should be between 20 and 60 minutes. A gel time of less than 20 minutes limits the workability of the grout during a process upset while it is in the facility and longer than 60 minutes can lead to settling and segregation of the grout. The specified gel range is to ensure processability through the facility and that sufficient microstructure develops once the grout is placed in the vault. Development of the structure over a short time period helps prevent segregation of the grout components. Bleed water on top of the set grout is an indication that segregation is occurring. ${ }^{15}$

The mixes had no bleed after one day except for mixes 18 and 24. The surface of these two samples was still wet after one day but there was not enough bleed to measure. In addition to no bleed, all of the grouts gelled within 60 minutes, which indicates there was no segregation occurring in the samples prior to microstructure development.

Table 3-1. Fresh grout properties for the 27 grout mixes.

\begin{tabular}{|c|c|c|c|c||}
\hline $\begin{array}{c}\text { Mix } \\
\text { Number }\end{array}$ & $\begin{array}{c}\text { Gel } \\
(\mathbf{m i n})\end{array}$ & $\begin{array}{c}\text { Fresh Density } \\
\text { (g/mL) }\end{array}$ & $\begin{array}{c}\text { Plastic } \\
\text { Viscosity (cP) }\end{array}$ & $\begin{array}{c}\text { Yield Stress } \\
\text { (Pa) }\end{array}$ \\
\hline \hline 1 & 35 & 1.725 & 113.70 & 6.07 \\
\hline 2 & 30 & 1.737 & 172.90 & 9.36 \\
\hline 3 & 20 & 1.745 & NM & NM \\
\hline 4 & 20 & 1.735 & 202.20 & 10.82 \\
\hline 5 & 45 & 1.682 & 79.40 & 4.37 \\
\hline 6 & 35 & 1.686 & 94.85 & 4.98 \\
\hline 7 & 35 & 1.692 & 87.94 & 4.73 \\
\hline 8 & 30 & 1.733 & 135.40 & 6.88 \\
\hline 9 & 45 & 1.730 & 133.30 & 6.39 \\
\hline 10 & 25 & 1.726 & 135.80 & 6.52 \\
\hline 11 & 50 & 1.680 & 65.22 & 3.20 \\
\hline 12 & 60 & 1.679 & 65.22 & 3.08 \\
\hline 13 & 40 & 1.679 & 72.09 & 3.46 \\
\hline 14 & 30 & 1.698 & 106.50 & 4.75 \\
\hline 15 & 30 & 1.735 & 167.10 & 7.55 \\
\hline 16 & 20 & 1.745 & 155.10 & 9.20 \\
\hline 17 & 20 & 1.751 & 168.00 & 8.10 \\
\hline 18 & 35 & 1.692 & 70.65 & 3.10 \\
\hline 19 & 40 & 1.697 & 74.68 & 3.31 \\
\hline 20 & 35 & 1.693 & 72.54 & 3.72 \\
\hline 21 & 25 & 1.721 & 135.40 & 6.88 \\
\hline 22 & 25 & 1.726 & 114.90 & 4.78 \\
\hline 23 & 25 & 1.726 & 114.90 & 4.67 \\
\hline 24 & 50 & 1.691 & 56.42 & 2.03 \\
\hline 25 & 40 & 1.693 & 57.66 & 2.20 \\
\hline 26 & 55 & 1.685 & 55.93 & 2.10 \\
\hline 27 & 30 & 1.736 & 75.08 & 3.67 \\
\hline \hline
\end{tabular}

NM - not measured 


\subsection{Young's Modulus}

Young's modulus, also known as the modulus of elasticity, is a measure of the stiffness of a material and is defined as the tensile stress divided by the tensile strain. ${ }^{18}$ Stiffer (or less elastic) materials have higher values of Young's modulus, E. Young's modulus has units of pressure which in this report are expressed as giga-pascals (GPa). Cement-based materials such as concrete have $\mathrm{E}$ values in the range of 5 - $30 \mathrm{GPa}$ with the actual values depending upon degree of hydration, the w/p ratio, and other factors. The Young's modulus for each mix is listed in ascending order in Table 3-2.

Table 3-2. Young's modulus values from lowest to highest and the associated operational and compositional factors for each mix.

\begin{tabular}{|c|c|c|c|c|c||}
\hline $\begin{array}{c}\text { Mix } \\
\text { Number }\end{array}$ & $\begin{array}{c}\text { Young's } \\
\text { Modulus (GPa) }\end{array}$ & $\begin{array}{c}\text { Curing } \\
\text { Temp }\left({ }^{\mathbf{}} \mathbf{C}\right)\end{array}$ & $\begin{array}{c}\text { Aluminate } \\
\text { Molarity }\end{array}$ & w/p & $\begin{array}{c}\text { Fly Ash } \\
\text { (wt \%) }\end{array}$ \\
\hline \hline 9 & 2.56 & 40 & 0.05 & 0.55 & 50 \\
\hline 13 & 2.56 & 60 & 0.05 & 0.65 & 50 \\
\hline 12 & 2.59 & 40 & 0.05 & 0.65 & 50 \\
\hline 26 & 2.64 & 60 & 0.28 & 0.65 & 50 \\
\hline 7 & 2.71 & 60 & 0.05 & 0.65 & 45 \\
\hline 6 & 2.94 & 40 & 0.05 & 0.65 & 45 \\
\hline 17 & 3.08 & 60 & 0.28 & 0.55 & 45 \\
\hline 20 & 3.33 & 60 & 0.28 & 0.65 & 45 \\
\hline 11 & 3.40 & 20 & 0.05 & 0.65 & 50 \\
\hline 10 & 3.67 & 60 & 0.05 & 0.55 & 50 \\
\hline 23 & 3.89 & 60 & 0.28 & 0.55 & 50 \\
\hline 4 & 4.25 & 60 & 0.05 & 0.55 & 45 \\
\hline 5 & 4.36 & 20 & 0.05 & 0.65 & 45 \\
\hline 3 & 4.56 & 40 & 0.05 & 0.55 & 45 \\
\hline 8 & 4.70 & 20 & 0.05 & 0.55 & 50 \\
\hline 25 & 4.92 & 40 & 0.28 & 0.65 & 50 \\
\hline 27 & 5.08 & 40 & 0.165 & 0.60 & 47.5 \\
\hline 14 & 5.21 & 40 & 0.165 & 0.60 & 47.5 \\
\hline 19 & 5.24 & 40 & 0.28 & 0.65 & 45 \\
\hline 2 & 5.56 & 20 & 0.05 & 0.55 & 45 \\
\hline 1 & 5.78 & 40 & 0.165 & 0.60 & 47.5 \\
\hline 22 & 6.71 & 40 & 0.28 & 0.55 & 50 \\
\hline 16 & 6.79 & 40 & 0.28 & 0.55 & 45 \\
\hline 24 & 8.77 & 20 & 0.28 & 0.65 & 50 \\
\hline 18 & 9.36 & 20 & 0.28 & 0.65 & 45 \\
\hline 21 & 10.54 & 20 & 0.28 & 0.55 & 50 \\
\hline 15 & 10.90 & 20 & 0.28 & 0.55 & 45 \\
\hline & & & & & \\
\hline
\end{tabular}

The results shown in Table 3-2 are graphically displayed in Figure 3-1 as a function of cure temperature. As shown in previous studies and literature, ${ }^{1,2,11}$ increasing the cure temperature decreases the Young's modulus of saltstone and grout. Literature shows that grouts heated to higher temperatures (greater than $60{ }^{\circ} \mathrm{C}$ ) lose additional moisture than grouts cured at room temperature. This leads to structural decomposition of the hydration products which results in 
serious loss in durability and strength. ${ }^{11,15,19}$ As shown in Table 3-3, the dehydration of the samples cured at higher temperatures is evidenced by the mass change between the fresh weight and the cured weight taken at 90 days. While there is variation in the data presented in Table 3-3 the general trend is the samples with the most weight loss were samples cured at $60{ }^{\circ} \mathrm{C}$.

The decrease in $\mathrm{E}$ with increasing temperature is also dependent on the aluminate molarity of the salt solution. At $20^{\circ} \mathrm{C}$, the grouts made with the high aluminate solution have higher $\mathrm{E}$ values than the low aluminate grouts. As shown in Figure 3-1, the increased strength due to high aluminate molarity is severely decreased as the cure temperature increases. It should be noted that the samples formulated with the low aluminate salt solution have E values that are relatively constant across the cure temperature profile as compared to the samples formulated with the higher aluminate solution. At $60{ }^{\circ} \mathrm{C}$, the Young's moduli of all the samples are similar and therefore, the compositional or operational factors of the grout mix do not appear to have an effect.

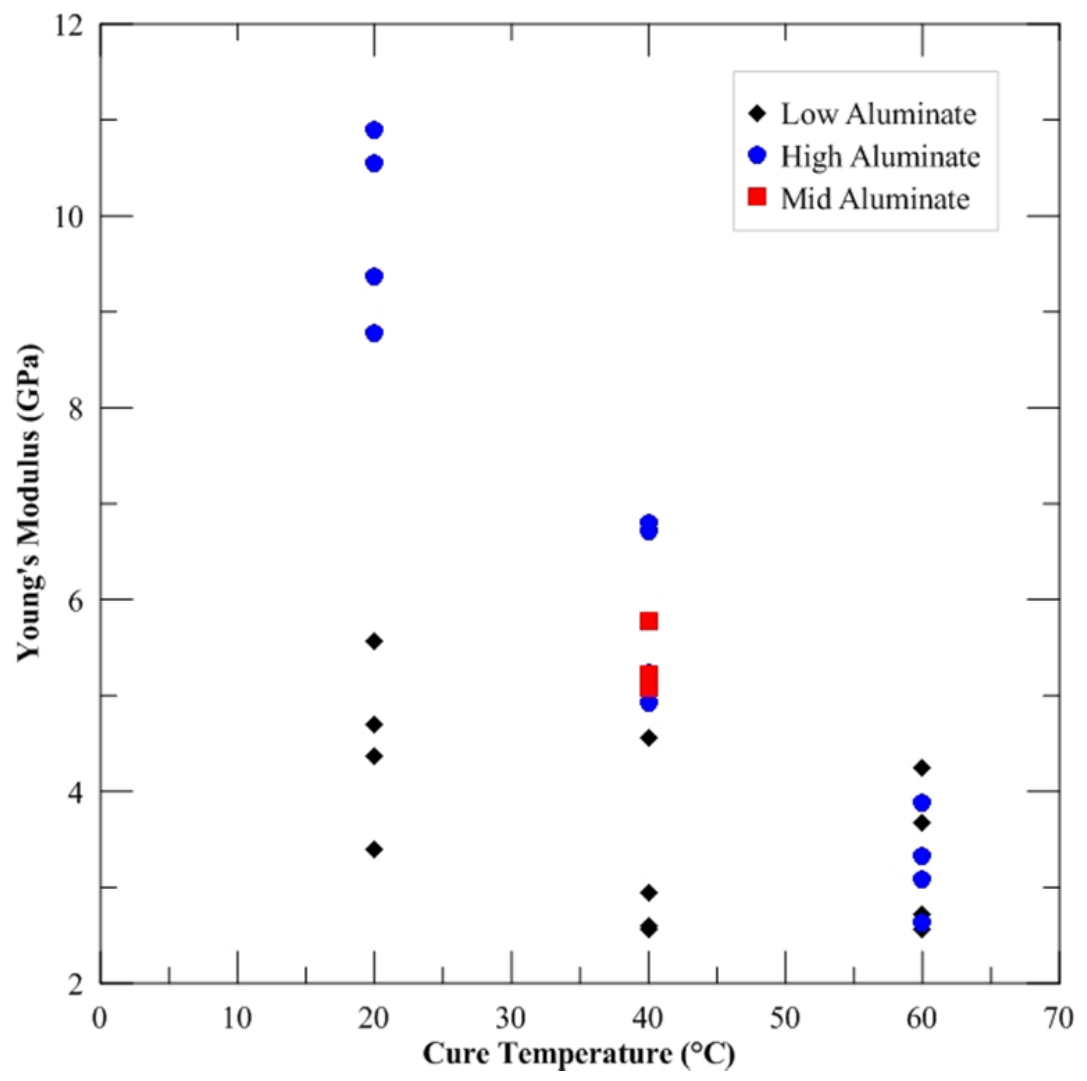

Figure 3-1. Young's modulus as a function of cure temperature for all grout mixes. 
Table 3-3. Grout mass loss after curing 90 days

\begin{tabular}{|c|c|c|c|c|c|}
\hline $\begin{array}{c}\text { Mix } \\
\text { Number }\end{array}$ & $\begin{array}{c}\text { Cure Temp } \\
\left({ }^{\circ} \mathrm{C}\right)\end{array}$ & $\begin{array}{c}\text { Mass Loss } \\
(\%)\end{array}$ & $\begin{array}{c}\text { Mix } \\
\text { Number }\end{array}$ & $\begin{array}{c}\text { Cure Temp } \\
\left({ }^{\circ} \mathrm{C}\right)\end{array}$ & $\begin{array}{c}\text { Mass Loss } \\
(\%)\end{array}$ \\
\hline 7 & 60 & 0.19 & 18 & 20 & 0.79 \\
\hline 25 & 40 & 0.27 & 4 & 60 & 0.83 \\
\hline 3 & 40 & 0.55 & 17 & 60 & 0.90 \\
\hline 15 & 20 & 0.59 & 10 & 60 & 0.94 \\
\hline 27 & 40 & 0.59 & 12 & 40 & 0.95 \\
\hline 1 & 40 & 0.62 & 26 & 60 & 0.96 \\
\hline 19 & 40 & 0.63 & 20 & 60 & 0.98 \\
\hline 16 & 40 & 0.63 & 11 & 20 & 0.99 \\
\hline 5 & 20 & 0.63 & 13 & 60 & 1.05 \\
\hline 8 & 20 & 0.64 & 9 & 40 & 1.06 \\
\hline 24 & 20 & 0.64 & 23 & 60 & 1.08 \\
\hline 6 & 40 & 0.64 & 18 & 20 & 0.79 \\
\hline 21 & 20 & 0.66 & 4 & 60 & 0.83 \\
\hline 22 & 40 & 0.67 & & & \\
\hline
\end{tabular}

Young's modulus is used as an indicator of the performance properties since there are multiple factors that can affect the $\mathrm{E}$ values of a grout sample, primarily porosity. ${ }^{15}$ One of the main factors that control the porosity of grouts is the water to premix ratio. In a previous study, it was demonstrated that the Young's modulus increases with decreasing w/p, ${ }^{7}$ The effect of w/p on E is confirmed by the results of this current study (Figure 3-2). However, the effect of lowering the $\mathrm{w} / \mathrm{p}$ ratio is negated at higher temperatures (Table 3-2). Therefore, for samples cured at $60{ }^{\circ} \mathrm{C}$, the Young's modulus is not a function of the water to premix ratio. 


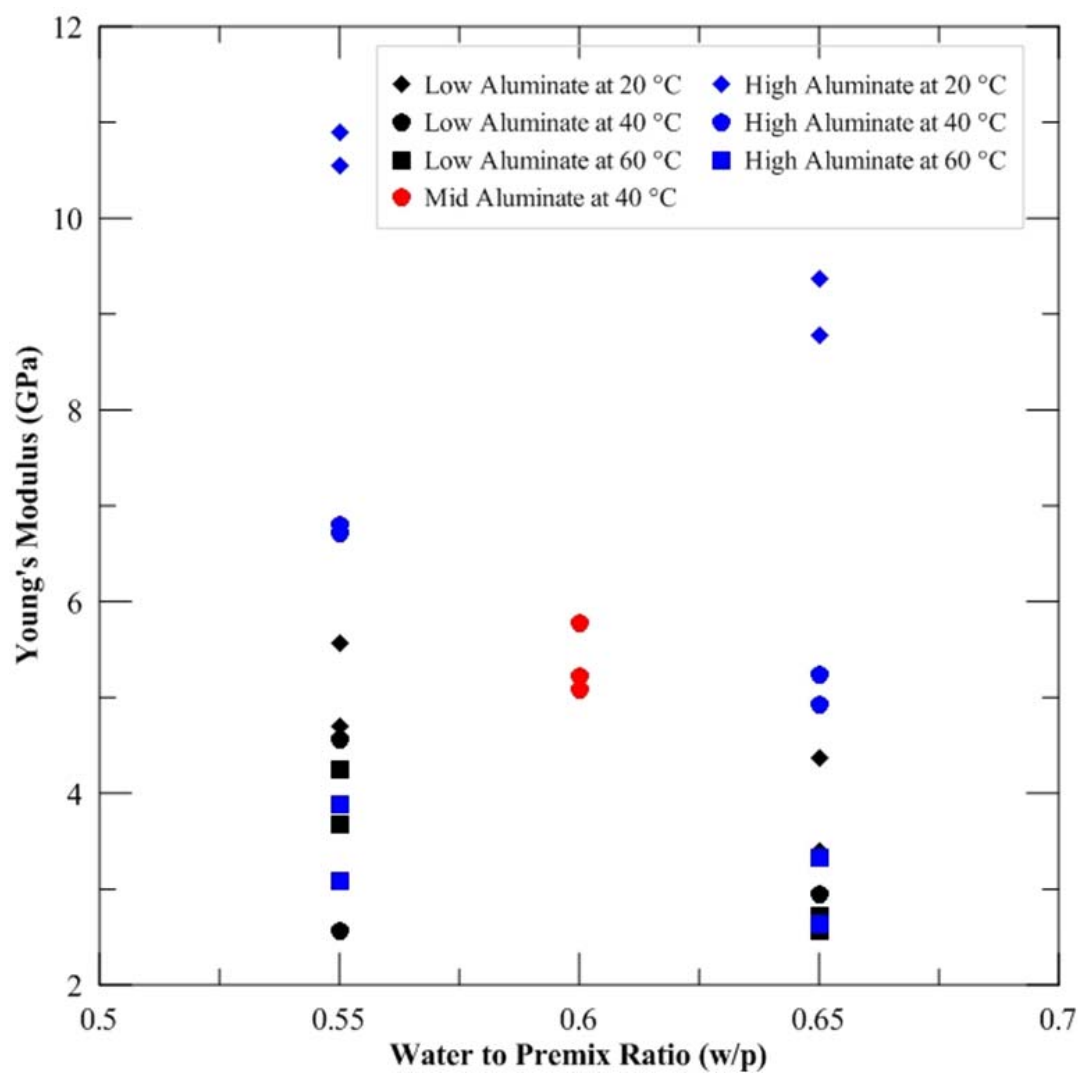

Figure 3-2. Young's modulus as a function of $w / p$ for all grouts.

Further analysis of the data shows that the Young's modulus of the grout is least dependent on the amount of fly ash in the premix. The negligible effect of fly ash content on Young's modulus is demonstrated in both Table 3-2 and Figure 3-3. The data suggest the other compositional and operational factors have a greater effect on the Young's modulus than the fly ash content in the premix. For a given mix where all other compositional and operational factors are held constant, increasing the fly ash will decrease value of Young's modulus; however the decreased values do not impact the performance of the grout as significantly as the other factors considered in this study.

Figure 3-3 is a variability chart that includes data from a prior study ${ }^{2}$ to demonstrate how the data from this study expand on previous data. APPENDIX A lists the data used from the previous report. This chart shows that saltstone made with high aluminate salt solution and cured at room temperature has the highest Young's modulus values of all grouts studied. As shown in Figure 3-1, the grout formulation does not factor into the value of Young's modulus for grouts cured at $60{ }^{\circ} \mathrm{C}$. The E variability chart also shows that grouts made at a $0.65 \mathrm{w} / \mathrm{p}$ ratio have lower E values than grouts batched at a w/p ratio of 0.55 . The reference mixes (1, 14, 27 shown as green dots) show that the method of analyzing Young's modulus is repeatable throughout the experiment. 


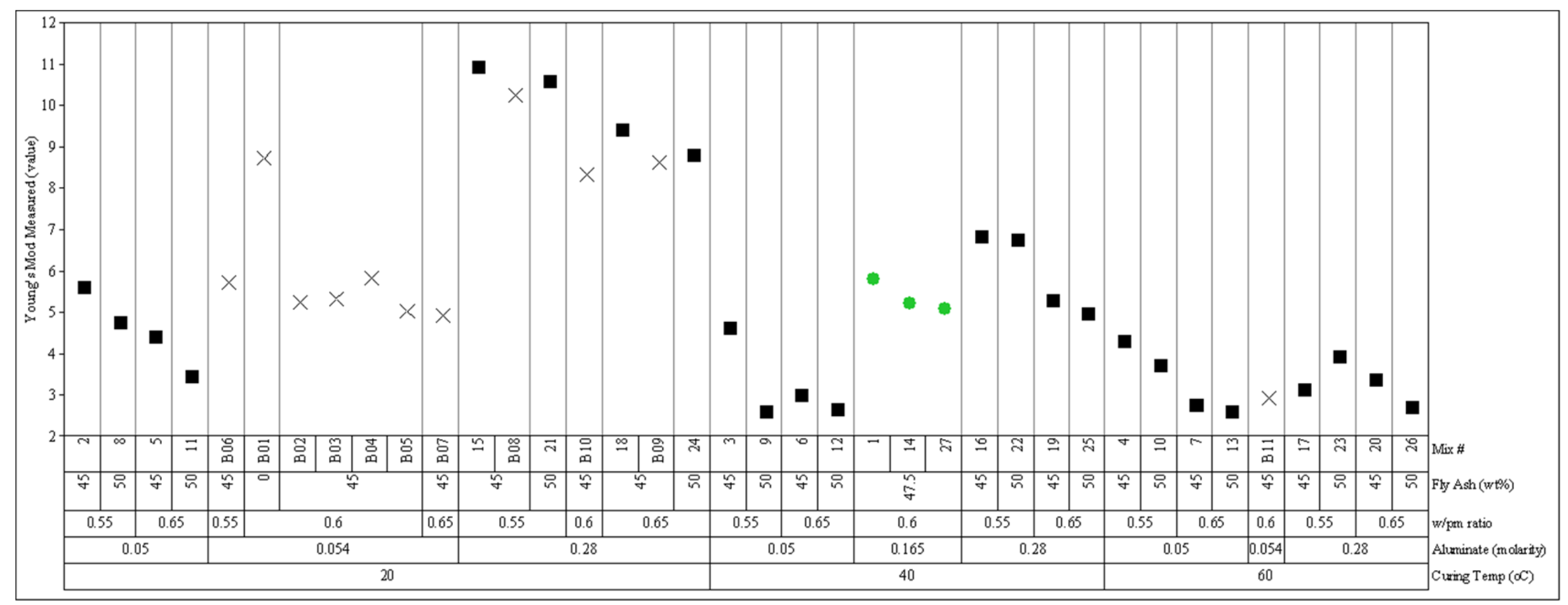

Figure 3-3. Variability chart for Young's modulus as a function of operational and compositional variables. 
The sample data were statistically analyzed to provide further insight into the operational and compositional factors that have the greatest effect on saltstone performance properties. For Young's modulus, a stepwise linear regression was conducted using $\mathrm{JMP}^{6}$, which lead to the model results presented in Figure 3-4 and Table 3-4. The fitted model yielded an $\mathrm{R}^{2}$ value of $94.9 \%$. Statistically significant main effects were indicated for aluminate, w/p, fly ash, and cure temperature, but there was also a statistically significant interaction between aluminate and cure temperature. The main effects indicate that Young's modulus tends to decrease as w/p increases and as fly ash increases. For aluminate and cure temperature, the effect is more complex as seen in Figure 3-1.

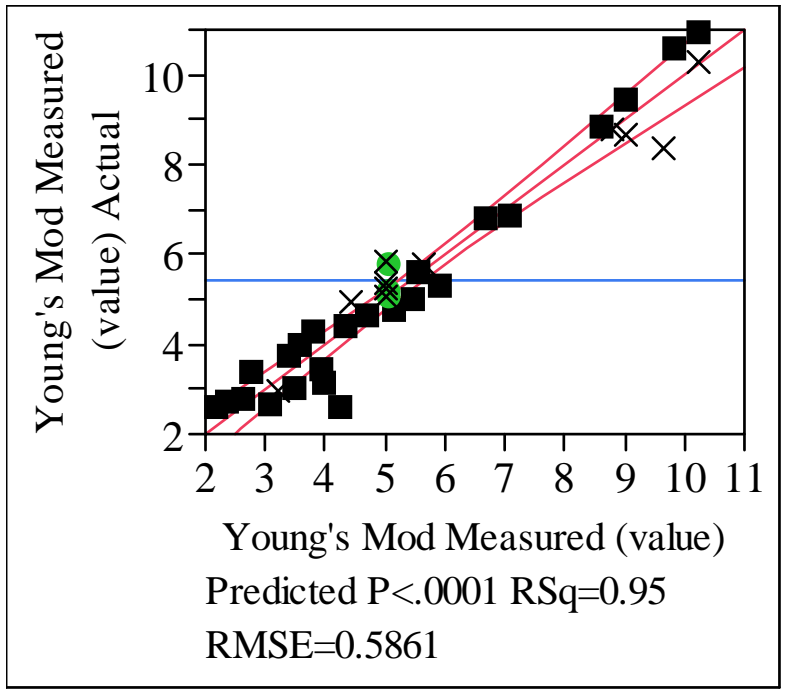

(a)

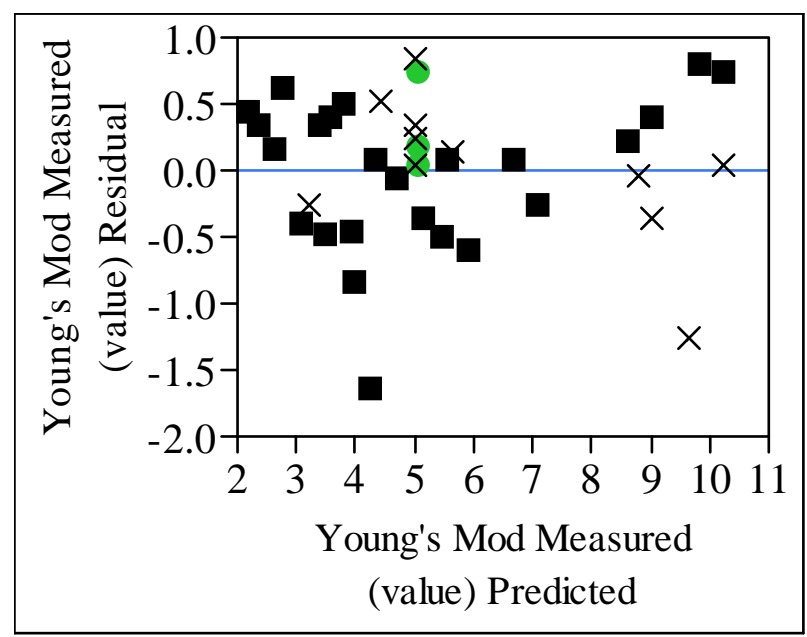

(b)

Figure 3-4. Response of Young's modulus due to operational and compositional variables, (a) actual by predicted and (b) residual by predicted. 
Table 3-4. Summary of fit for the response of Young's modulus values compared to the predicted model

\begin{tabular}{||l|c|}
\hline \multicolumn{2}{|c|}{ Summary of Fit } \\
\hline \hline R Square & 0.949 \\
\hline R Square Adj & 0.941 \\
\hline Root Mean Square Error & 0.586 \\
\hline Mean of Response & 5.439 \\
\hline Observations (or Sum Wgts) & 38 \\
\hline \hline
\end{tabular}

\begin{tabular}{|c|c|c|c|c|}
\hline \multicolumn{5}{|c|}{ Analysis of Variance } \\
\hline Source & DF & Sum of Squares & Mean Square & F Ratio \\
\hline Model & 5 & 203.88061 & 40.7761 & 118.6908 \\
\hline Error & 32 & 10.99358 & 0.3435 & Prob $>$ F \\
\hline C. Total & 37 & 214.87419 & -- & $<.0001$ \\
\hline Source & DF & Sum of Squares & Mean Square & F Ratio \\
\hline Lack Of Fit & 25 & 9.835009 & 0.3934 & 2.3769 \\
\hline Pure Error & 7 & 1.158567 & 0.16551 & -- \\
\hline \multirow{2}{*}{ Total Error } & \multirow{2}{*}{32} & \multirow{2}{*}{10.993575} & Prob $>$ F & 0.1199 \\
\hline & & & Max RSq & 0.9946 \\
\hline \multicolumn{5}{|c|}{ Parameter Estimates } \\
\hline Term & Estimate & Std Error & t Ratio & Prob $>|t|$ \\
\hline Intercept & 17.843 & 1.448 & 12.32 & $<.0001$ \\
\hline Aluminate (molarity) & 12.857 & 0.888 & 14.47 & $<.0001$ \\
\hline w/p ratio & -11.993 & 2.215 & -5.41 & $<.0001$ \\
\hline Fly Ash (wt\%) & -0.084 & 0.013 & -6.62 & $<.0001$ \\
\hline Curing Temp $\left({ }^{\circ} \mathrm{C}\right)$ & -0.093 & 0.006 & -15.46 & $<.0001$ \\
\hline $\begin{array}{l}\text { (Aluminate (molarity)-0.15071)* } \\
\left.\text { (Curing Temp }\left({ }^{\circ} \mathrm{C}\right)-35.2632\right)\end{array}$ & -0.490 & 0.053 & -9.30 & $<.0001$ \\
\hline
\end{tabular}

\subsection{Hydraulic Conductivity}

Permeability is defined as the property that governs the rate of flow of a fluid into a porous solid. For steady-state flow, the coefficient of permeability, also known as hydraulic conductivity, is determined by Darcy's equation (Equation 1). ${ }^{15}$ The saturated hydraulic conductivity (Table 3-5) was determined after the sample had cured 90 days. 
Table 3-5. Hydraulic conductivity values listed from highest to lowest and the associated operational and compositional factors for each mix.

\begin{tabular}{|c|c|c|c|c|c||}
\hline $\begin{array}{c}\text { Mix } \\
\text { Number }\end{array}$ & $\begin{array}{c}\text { Hydraulic } \\
\text { Conductivity (cm/s) }\end{array}$ & $\begin{array}{c}\text { Aluminate } \\
\text { Molarity }\end{array}$ & $\begin{array}{c}\text { Curing } \\
\text { Temp }\left({ }^{\circ} \mathbf{C}\right)\end{array}$ & w/p & $\begin{array}{c}\text { Fly Ash } \\
\text { (wt \%) }\end{array}$ \\
\hline \hline 12 & $1.90 \mathrm{E}-06$ & 0.05 & 40 & 0.65 & 50 \\
\hline 7 & $1.27 \mathrm{E}-06$ & 0.05 & 60 & 0.65 & 45 \\
\hline 6 & $9.13 \mathrm{E}-07$ & 0.05 & 40 & 0.65 & 45 \\
\hline 4 & $9.10 \mathrm{E}-07$ & 0.05 & 60 & 0.55 & 45 \\
\hline 13 & $7.13 \mathrm{E}-07$ & 0.05 & 60 & 0.65 & 50 \\
\hline 10 & $6.67 \mathrm{E}-07$ & 0.05 & 60 & 0.55 & 50 \\
\hline 17 & $4.03 \mathrm{E}-07$ & 0.28 & 60 & 0.55 & 45 \\
\hline 26 & $3.33 \mathrm{E}-07$ & 0.28 & 60 & 0.65 & 50 \\
\hline 9 & $2.80 \mathrm{E}-07$ & 0.05 & 40 & 0.55 & 50 \\
\hline 3 & $2.50 \mathrm{E}-07$ & 0.05 & 40 & 0.55 & 45 \\
\hline 20 & $1.90 \mathrm{E}-07$ & 0.28 & 60 & 0.65 & 45 \\
\hline 23 & $6.20 \mathrm{E}-08$ & 0.28 & 60 & 0.55 & 50 \\
\hline 11 & $4.93 \mathrm{E}-08$ & 0.05 & 20 & 0.65 & 50 \\
\hline 1 & $3.13 \mathrm{E}-08$ & 0.165 & 40 & 0.6 & 47.5 \\
\hline 14 & $3.00 \mathrm{E}-08$ & 0.165 & 40 & 0.6 & 47.5 \\
\hline 27 & $2.97 \mathrm{E}-08$ & 0.165 & 40 & 0.6 & 47.5 \\
\hline 5 & $2.40 \mathrm{E}-08$ & 0.05 & 20 & 0.65 & 45 \\
\hline 21 & $2.13 \mathrm{E}-08$ & 0.28 & 20 & 0.55 & 50 \\
\hline 8 & $1.68 \mathrm{E}-08$ & 0.05 & 20 & 0.55 & 50 \\
\hline 25 & $1.59 \mathrm{E}-08$ & 0.28 & 40 & 0.65 & 50 \\
\hline 24 & $5.37 \mathrm{E}-09$ & 0.28 & 20 & 0.65 & 50 \\
\hline 2 & $4.13 \mathrm{E}-09$ & 0.05 & 20 & 0.55 & 45 \\
\hline 15 & $2.87 \mathrm{E}-09$ & 0.28 & 20 & 0.55 & 45 \\
\hline 18 & $2.87 \mathrm{E}-09$ & 0.28 & 20 & 0.65 & 45 \\
\hline 19 & $2.70 \mathrm{E}-09$ & 0.28 & 40 & 0.65 & 45 \\
\hline 22 & $2.27 \mathrm{E}-09$ & 0.28 & 40 & 0.55 & 50 \\
\hline 16 & $1.04 \mathrm{E}-09$ & 0.28 & 40 & 0.55 & 45 \\
\hline
\end{tabular}

As shown in Table 3-5 and Figure 3-5 the curing temperature has an effect on the hydraulic conductivity of the saltstone samples. As discussed in Section 3.2, the increased temperature can lead to decreased durability and strength. One proposed mechanism for the lowered performance properties as a result of increased temperature is microcracking ${ }^{19}$ which would result in a higher measured hydraulic conductivity. 


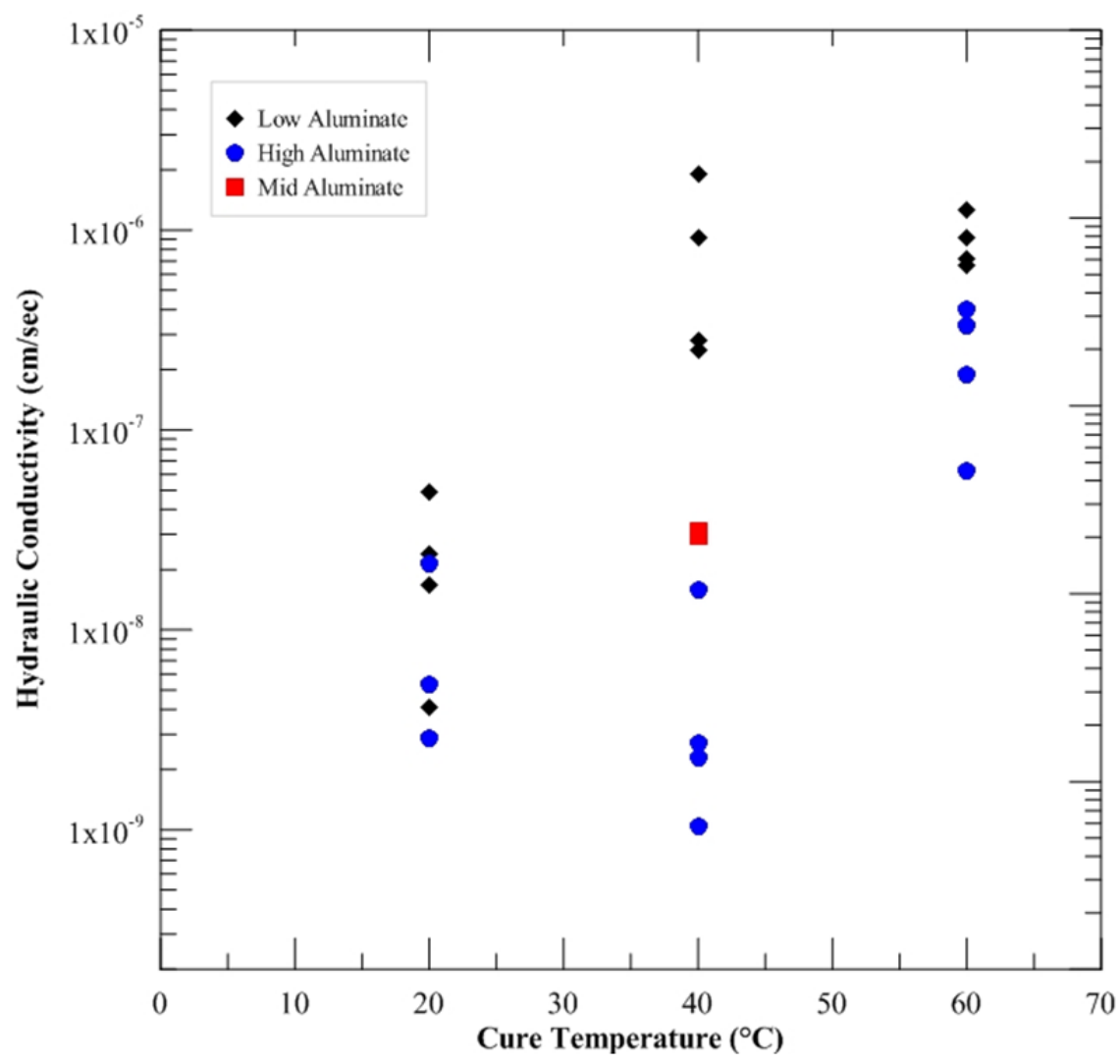

Figure 3-5. Hydraulic conductivity as a function of cure temperature for 27 grout mixes.

The samples made with the low aluminate simulant have generally higher hydraulic conductivities than the samples formulated with the high aluminate solution which is consistent with previous results. ${ }^{2}$ At $40{ }^{\circ} \mathrm{C}$, the high aluminate samples have an improved hydraulic conductivity compared to the hydraulic conductivity of the samples cured at $20^{\circ} \mathrm{C}$. However, the opposite occurs for the grouts made with the low aluminate simulant. Further investigation needs to be performed to determine the cause of these results.

It has been shown in literature that the hydraulic conductivity of cement pastes is primarily determined by the size and continuity of pores. ${ }^{15}$ One of the primary compositional factors that control the porosity of the saltstone is the water to premix ratio (Section 3.4). Therefore, the hydraulic conductivity should be affected by the water to premix ratio of the grout mix (Figure 3-6). There is a general trend that increasing the w/p, increases the hydraulic conductivity of the grout, but the data do not lead to any definite conclusions. 


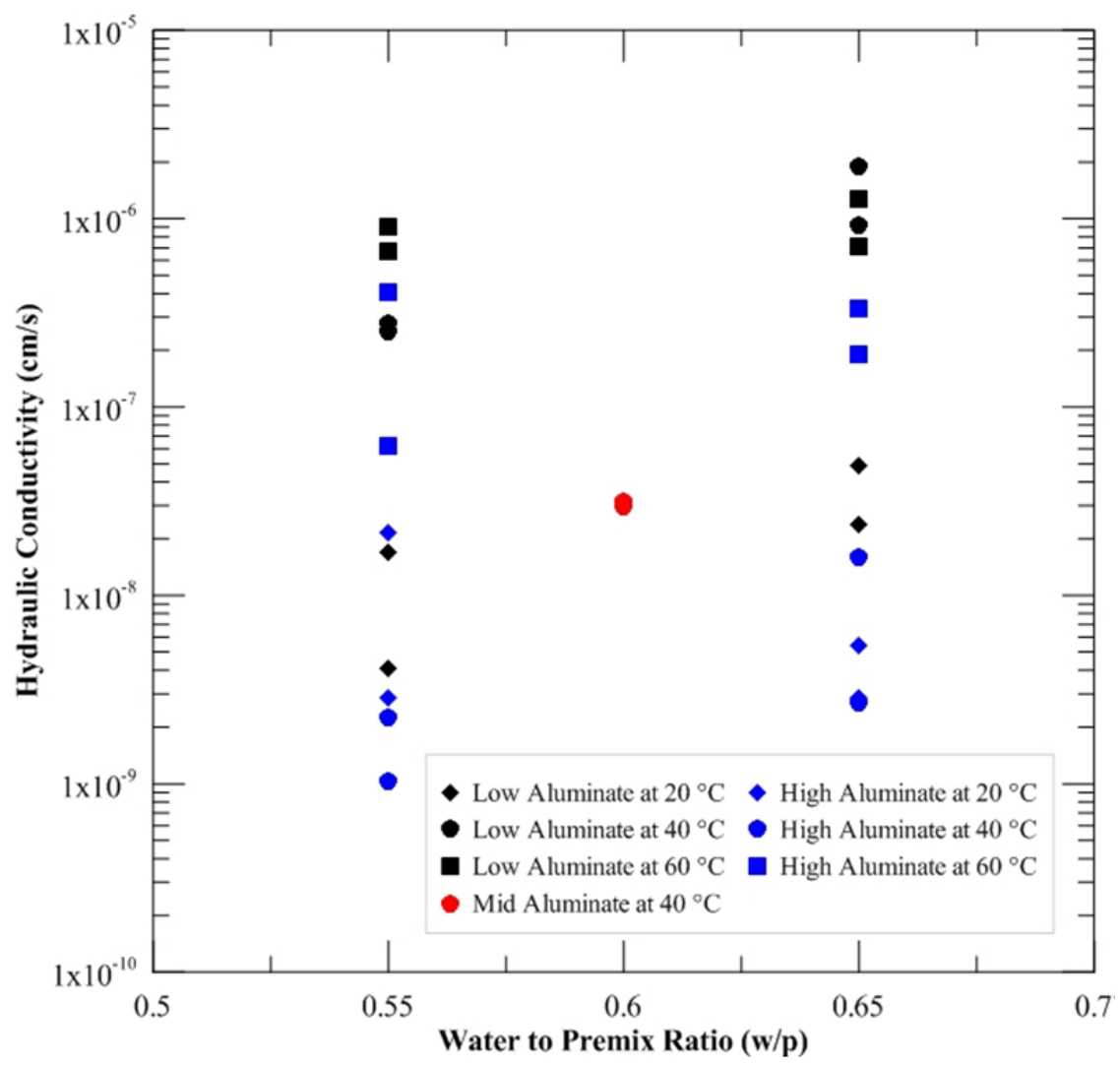

Figure 3-6. Hydraulic Conductivity as a function of w/p for all mixes.

The variability of the saturated hydraulic conductivity as a function of the operational and compositional factors of the grout mixes is presented in Figure 3-7. Included in the chart are the sample data from the previous study on ARP/MCU saltstone (marked as X's in Figure 3-7). The mix designs for the previous samples are listed in Appendix A. ${ }^{2}$ The references mixes (green dots) for this study show little variability in their values of hydraulic conductivity, indicating repeatability throughout the experiment. In general, the fly ash content in the premix increases the hydraulic conductivity of the grout. This is primarily evident for samples cured at lower temperatures. 


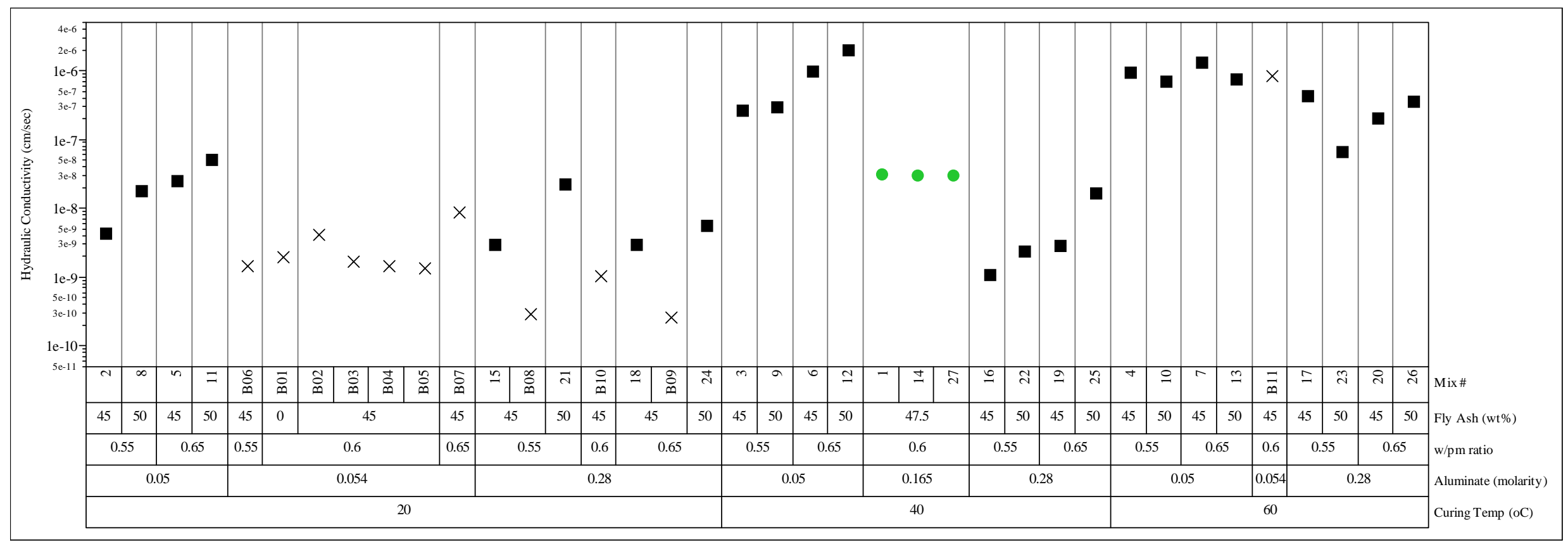

Figure 3-7. Variability chart for hydraulic conductivity as a function of operational and compositional variables. 
The sample data were statistically analyzed to provide further insight into the operational and compositional factors that have the greatest effect on the hydraulic conductivity of saltstone. Stepwise linear regression was used to model the common logarithm of hydraulic conductivity; the results are given in Figure 3-8 and Table 3-6. The $\mathrm{R}^{2}$ value for the fitted model is $73.6 \%$. Statistically significant events are indicated for aluminate and for cure temperature. Based upon estimated effects, as aluminate increases the hydraulic conductivity tends to decrease, and as curing temperature increases, the hydraulic conductivity tends to increase.

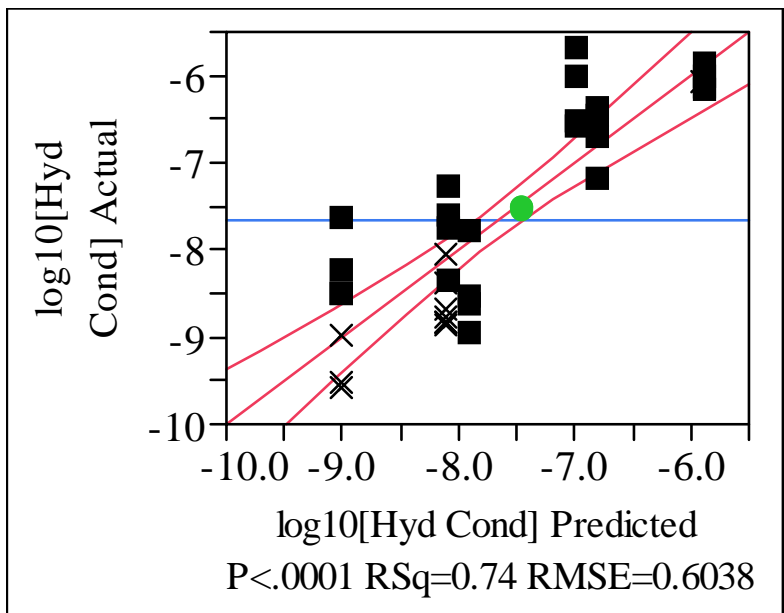

(a)

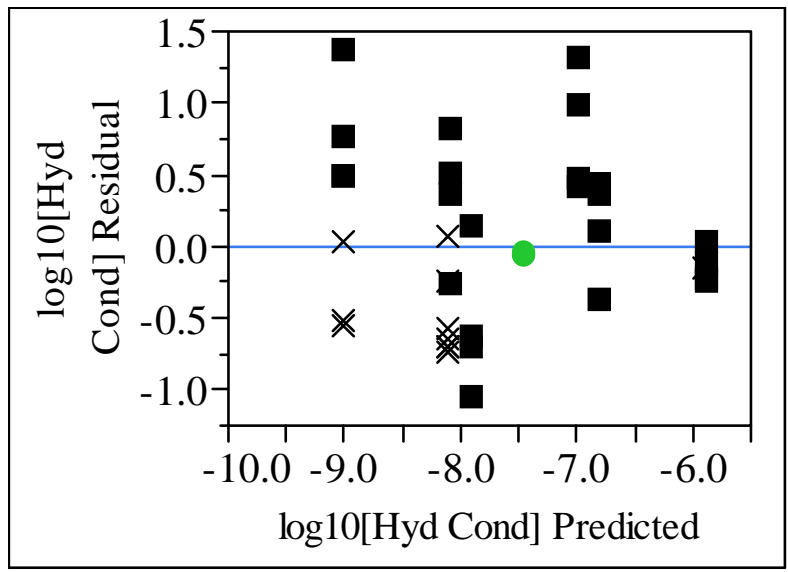

(b)

Figure 3-8. Response of hydraulic conductivity due to operational and compositional variables, (a) actual by predicted and (b) residual by predicted. 
Table 3-6. Summary of fit for the response of common logarithm of hydraulic conductivity values compared to the predicted model

\begin{tabular}{|c|c|c|c|c|}
\hline \multicolumn{2}{|l|}{ Summary of Fit } & & & \\
\hline R Square & 0.736 & & & \\
\hline R Square Adj & 0.721 & & & \\
\hline Root Mean Square Error & 0.604 & & & \\
\hline Mean of Response & -7.670 & & & \\
\hline Observations (or Sum Wgts) & 38 & & & \\
\hline \multicolumn{5}{|c|}{ Analysis of Variance } \\
\hline Source & DF & Sum of Squares & Mean Square & F Ratio \\
\hline Model & 2 & 35.573403 & 17.7867 & 48.793 \\
\hline Error & 35 & 12.758674 & 0.3645 & Prob $>$ F \\
\hline C. Total & 37 & 48.332077 & -- & $<.0001$ \\
\hline Source & DF & Sum of Squares & Mean Square & F Ratio \\
\hline Lack Of Fit & 6 & 6.936777 & 1.15613 & 5.7589 \\
\hline Pure Error & 29 & 5.821898 & 0.20076 & -- \\
\hline \multirow{2}{*}{ Total Error } & \multirow{2}{*}{35} & \multirow{2}{*}{12.758674} & Prob $>$ F & 0.0005 \\
\hline & & & Max RSq & 0.8795 \\
\hline \multicolumn{5}{|c|}{ Parameter Estimates } \\
\hline Term & Estimate & Std Error & t Ratio & Prob $>|t|$ \\
\hline Intercept & -9.018013 & 0.265528 & -33.96 & $<.0001$ \\
\hline Aluminate (molarity) & -3.957947 & 0.903668 & -4.38 & 0.0001 \\
\hline Curing Temp $\left({ }^{\circ} \mathrm{C}\right)$ & 0.055133 & 0.006064 & 9.09 & $<.0001$ \\
\hline
\end{tabular}

\subsection{Porosity}

Grout porosity is generally defined as the percentage of total volume of cured grout that is not occupied by either the starting cementitious materials (in this case, portland cement, blast furnace slag, and Class F fly ash) or the products that results from reaction of these cementitious materials with water (calcium silicate hydrate, calcium hydroxide crystals, etc.) ${ }^{15}$ For saltstone mixes, the pore volume is occupied by a salt solution.

Table 3-7 lists the percent porosity from lowest to highest for all mixes batched for this study. The data show that the majority of the grouts batched at the lower water to premix ratio correspond with lower porosity values (Figure 3-9). In general, grouts with higher w/p have increased porosity assuming that the cementitious materials are completely hydrated. ${ }^{15}$

The data also show a general tendency for cure temperature to affect the porosity of the cured grout. This relationship will be further discussed in Section 3.7. 
Table 3-7. Porosity values listed from lowest to highest and the associated operational and compositional factors for each mix.

\begin{tabular}{|c|c|c|c|c|c|}
\hline $\begin{array}{c}\text { Mix } \\
\text { Number }\end{array}$ & $\begin{array}{c}\text { Porosity } \\
(\mathbf{\%})\end{array}$ & w/p & $\begin{array}{c}\text { Aluminate } \\
\text { Molarity }\end{array}$ & $\begin{array}{c}\text { Fly Ash } \\
\text { (wt } \%)\end{array}$ & $\begin{array}{c}\text { Curing } \\
\left.\text { Temp } \mathbf{~}^{\circ} \mathbf{C}\right)\end{array}$ \\
\hline \hline 21 & 54.9 & 0.55 & 0.28 & 50 & 20 \\
\hline 15 & 55.8 & 0.55 & 0.28 & 45 & 20 \\
\hline 3 & 56.5 & 0.55 & 0.05 & 45 & 40 \\
\hline 13 & 57.6 & 0.65 & 0.05 & 50 & 60 \\
\hline 23 & 57.6 & 0.55 & 0.28 & 50 & 60 \\
\hline 8 & 57.9 & 0.55 & 0.05 & 50 & 20 \\
\hline 11 & 57.9 & 0.65 & 0.05 & 50 & 20 \\
\hline 22 & 58.1 & 0.55 & 0.28 & 50 & 40 \\
\hline 16 & 58.3 & 0.55 & 0.28 & 45 & 40 \\
\hline 2 & 58.4 & 0.55 & 0.05 & 45 & 20 \\
\hline 9 & 58.6 & 0.55 & 0.05 & 50 & 40 \\
\hline 1 & 59.0 & 0.60 & 0.165 & 47.5 & 40 \\
\hline 10 & 59.3 & 0.55 & 0.05 & 50 & 60 \\
\hline 17 & 59.7 & 0.55 & 0.28 & 45 & 60 \\
\hline 14 & 59.8 & 0.60 & 0.165 & 47.5 & 40 \\
\hline 18 & 60.0 & 0.65 & 0.28 & 45 & 20 \\
\hline 4 & 60.2 & 0.55 & 0.05 & 45 & 60 \\
\hline 24 & 60.6 & 0.65 & 0.28 & 50 & 20 \\
\hline 27 & 61.1 & 0.60 & 0.165 & 47.5 & 40 \\
\hline 12 & 62.1 & 0.65 & 0.05 & 50 & 40 \\
\hline 5 & 62.2 & 0.65 & 0.05 & 45 & 20 \\
\hline 26 & 62.7 & 0.65 & 0.28 & 50 & 60 \\
\hline 6 & 63.3 & 0.65 & 0.05 & 45 & 40 \\
\hline 7 & 63.3 & 0.65 & 0.05 & 45 & 60 \\
\hline 19 & 63.4 & 0.65 & 0.28 & 45 & 40 \\
\hline 20 & 63.8 & 0.65 & 0.28 & 45 & 60 \\
\hline 25 & 68.3 & 0.65 & 0.28 & 50 & 40 \\
\hline & & & & & \\
\hline \hline
\end{tabular}




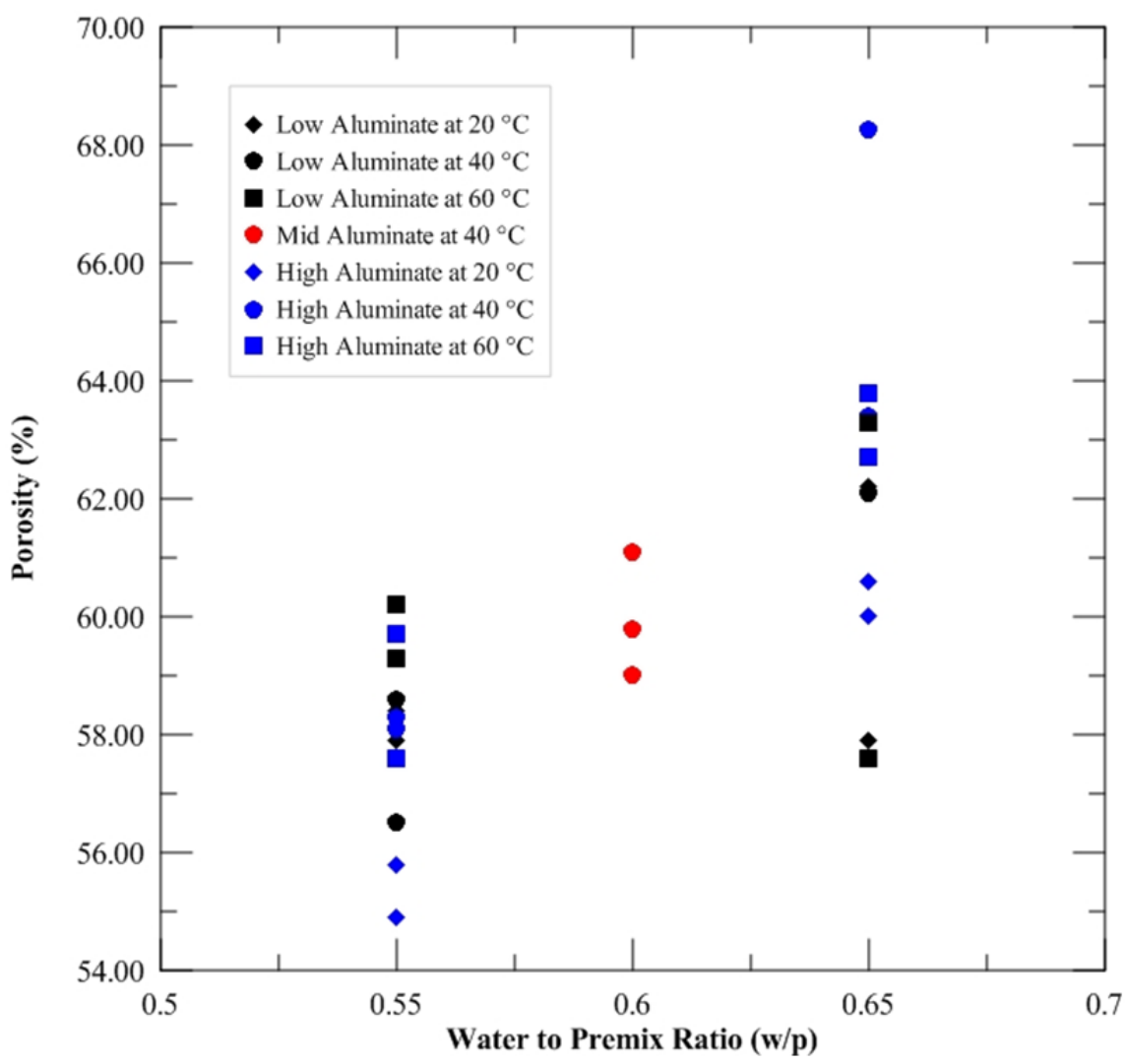

Figure 3-9. Porosity as a function of $\mathbf{w} / \mathbf{p}$ for all mixes.

Figure 3-10 shows the variability of the measured porosity of saltstone compared to compositional and operational factors varied in this study as well as data from a previous study (gray X's). ${ }^{2}$ As shown by the values of the reference mixes (green dots), the measured porosity can vary between mixes yet stay within approximately $2 \%$. The variability chart shows little correlation between fly ash content in the premix and porosity of the grout. The data in Figure 3-9 and Figure 3-10 show a slight correlation between high aluminate grouts cured at $20{ }^{\circ} \mathrm{C}$ and low porosity; however there is no distinct relationship between aluminate content of the salt solution and cured grout porosity. 


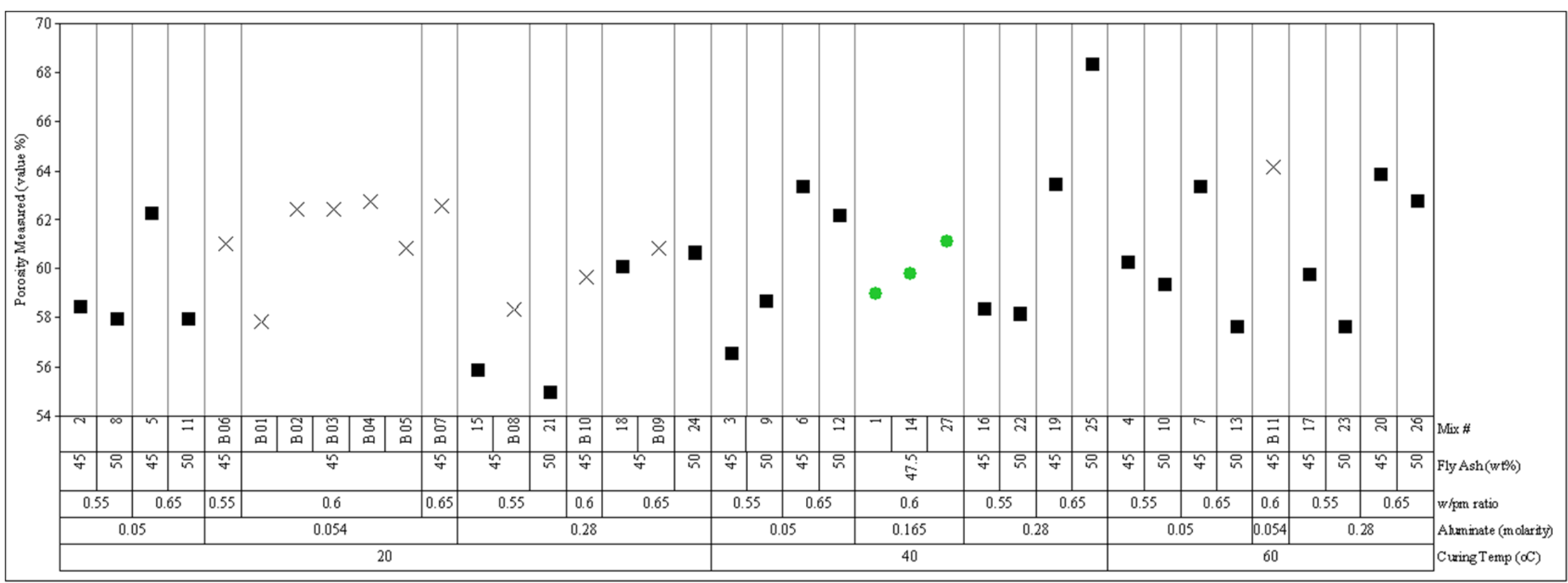

Figure 3-10. Variability chart for porosity as a function of operational and compositional variables. 
The sample data was statistically analyzed to provide further insight into the operational and compositional factors that have the greatest effect on the porosity of saltstone. Stepwise linear regression was used to model porosity; the results are given in Table 3-8 and Figure 3-1. The $\mathrm{R}^{2}$ value for the fitted model is only $56.4 \%$ even though several terms, including interactions, were included in the final model form and a significance level of $10 \%$ was utilized. The most significant effects are those due to w/p (which indicates there is a tendency for porosity to increase as $\mathrm{w} / \mathrm{p}$ increases) and curing temperature (which indicates there is a tendency for porosity to increase as curing temperature increases).

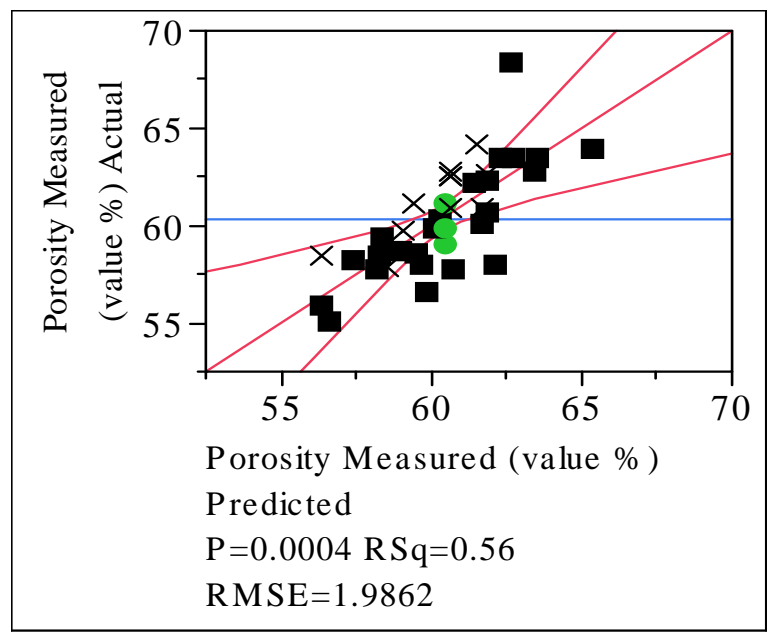

(a)

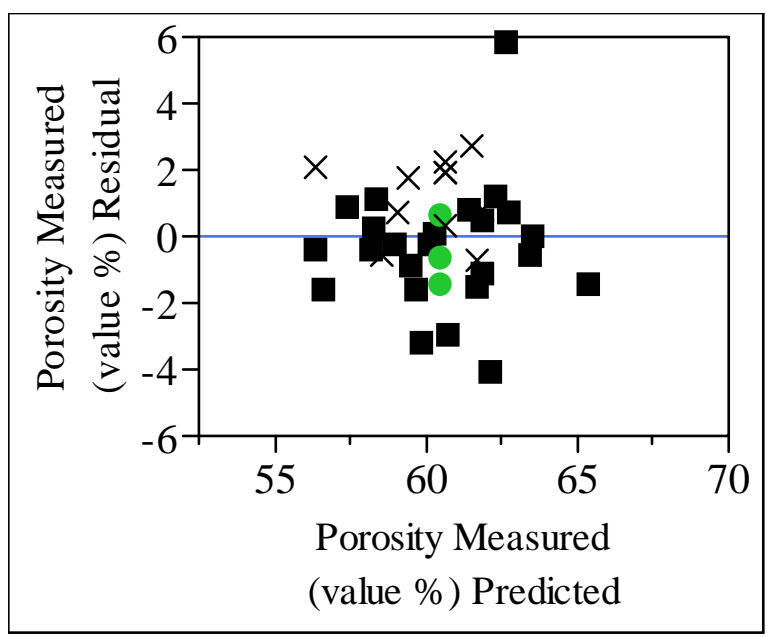

(b)

Figure 3-11. Response of porosity due to operational and compositional variables, (a) actual by predicted and (b) residual by predicted. 
Table 3-8. Summary of fit for the response of porosity values compared to the predicted model

\begin{tabular}{|c|c|c|c|c|}
\hline \multicolumn{2}{|l|}{ Summary of Fit } & & & \\
\hline R Square & 0.564 & & & \\
\hline R Square Adj & 0.462 & & & \\
\hline Root Mean Square Error & 1.986 & & & \\
\hline Mean of Response & 60.337 & & & \\
\hline Observations (or Sum Wgts) & 38 & & & \\
\hline \multicolumn{5}{|c|}{ Analysis of Variance } \\
\hline Source & DF & Sum of Squares & Mean Square & F Ratio \\
\hline Model & 7 & 153.08149 & 21.8688 & 5.5436 \\
\hline Error & 30 & 118.34693 & 3.9449 & Prob $>F$ \\
\hline C. Total & 37 & 271.42842 & -- & 0.0004 \\
\hline Source & DF & Sum of Squares & Mean Square & F Ratio \\
\hline Lack Of Fit & 23 & 110.42776 & 4.80121 & 4.2439 \\
\hline Pure Error & 7 & 7.91917 & 1.13131 & -- \\
\hline \multirow{2}{*}{ Total Error } & \multirow{2}{*}{30} & \multirow{2}{*}{118.34693} & Prob $>$ F & 0.0281 \\
\hline & & & Max RSq & 0.9708 \\
\hline \multicolumn{5}{|c|}{ Parameter Estimates } \\
\hline Term & Estimate & Std Error & t Ratio & Prob $>|t|$ \\
\hline Intercept & 42.8513 & 6.1684 & 6.9500 & $<.0001$ \\
\hline Aluminate (molarity) & -2.3421 & 3.0106 & -0.7800 & 0.4427 \\
\hline w/p ratio & 36.6971 & 7.5674 & 4.8500 & $<.0001$ \\
\hline Fly Ash (wt\%) & -0.1216 & 0.0950 & -1.2800 & 0.2103 \\
\hline Curing Temp $\left({ }^{\circ} \mathrm{C}\right)$ & 0.0461 & 0.0224 & 2.0600 & 0.0481 \\
\hline $\begin{array}{l}\text { (Aluminate (molarity)- } 0.15071) \\
*(\mathrm{w} / \mathrm{p} \text { ratio- } 0.6)\end{array}$ & 123.6995 & 65.4388 & 1.8900 & 0.0684 \\
\hline $\begin{array}{l}\text { (Aluminate (molarity)-0.15071) } \\
\left.* \text { (Curing Temp }\left({ }^{\circ} \mathrm{C}\right)-35.2632\right)\end{array}$ & 0.3156 & 0.1794 & 1.7600 & 0.0887 \\
\hline $\begin{array}{l}\text { (Fly Ash (wt\%)-45.5921) } \\
\left.* \text { (Curing Temp }\left({ }^{\circ} \mathrm{C}\right)-35.2632\right)\end{array}$ & -0.0111 & 0.0062 & -1.7900 & 0.0831 \\
\hline
\end{tabular}

\subsection{Cured Density}

The cured density of the grouts is calculated from the cured weight after 90 days and the length and diameter of a 3x6 inch cylinder. Table 3-9 lists the cured densities for each mix in ascending order. The grouts formulated at $0.65 \mathrm{w} / \mathrm{p}$ are less dense than the grouts made at $0.55 \mathrm{w} / \mathrm{p}$ (Figure 3-12). Lower w/p mixes have smaller capillary voids than those formulated at higher w/p which results in an overall denser grout. Grouts formulated at higher water to premix have greater volume expansion due to pore size to accommodate the additional liquid. ${ }^{15}$ In addition, the cure temperature has an effect on the density of the grout. The grouts cured at $60{ }^{\circ} \mathrm{C}$ have lower densities than the other grouts, which is indicative of drying the sample and loss of pore solution (Table 3-3). 
Table 3-9. Cured density values listed from lowest to highest and the associated operational and compositional factors for each mix.

\begin{tabular}{|c|c|c|c|c|c||}
\hline $\begin{array}{c}\text { Mix } \\
\text { Number }\end{array}$ & $\begin{array}{c}\text { Cured } \\
\text { Density (g/mL) }\end{array}$ & w/p & $\begin{array}{c}\text { Aluminate } \\
\text { Molarity }\end{array}$ & $\begin{array}{c}\text { Fly Ash } \\
\text { (wt \%) }\end{array}$ & $\begin{array}{c}\text { Curing } \\
\left.\text { Temp ( }{ }^{\circ} \mathbf{C}\right)\end{array}$ \\
\hline \hline 11 & 1.597 & 0.65 & 0.05 & 50 & 20 \\
\hline 5 & 1.704 & 0.65 & 0.05 & 45 & 20 \\
\hline 18 & 1.706 & 0.65 & 0.28 & 45 & 20 \\
\hline 6 & 1.707 & 0.65 & 0.05 & 45 & 40 \\
\hline 7 & 1.708 & 0.65 & 0.05 & 45 & 60 \\
\hline 4 & 1.711 & 0.55 & 0.05 & 45 & 60 \\
\hline 20 & 1.711 & 0.65 & 0.28 & 45 & 60 \\
\hline 26 & 1.717 & 0.65 & 0.28 & 50 & 60 \\
\hline 24 & 1.721 & 0.65 & 0.28 & 50 & 20 \\
\hline 13 & 1.727 & 0.65 & 0.05 & 50 & 60 \\
\hline 23 & 1.733 & 0.55 & 0.28 & 50 & 60 \\
\hline 19 & 1.735 & 0.65 & 0.28 & 45 & 40 \\
\hline 12 & 1.742 & 0.65 & 0.05 & 50 & 40 \\
\hline 14 & 1.742 & 0.60 & 0.165 & 47.5 & 40 \\
\hline 21 & 1.745 & 0.55 & 0.28 & 50 & 20 \\
\hline 27 & 1.745 & 0.60 & 0.165 & 47.5 & 40 \\
\hline 8 & 1.747 & 0.55 & 0.05 & 50 & 20 \\
\hline 25 & 1.747 & 0.65 & 0.28 & 50 & 40 \\
\hline 1 & 1.755 & 0.60 & 0.165 & 47.5 & 40 \\
\hline 10 & 1.757 & 0.55 & 0.05 & 50 & 60 \\
\hline 15 & 1.764 & 0.55 & 0.28 & 45 & 20 \\
\hline 17 & 1.769 & 0.55 & 0.28 & 45 & 60 \\
\hline 22 & 1.771 & 0.55 & 0.28 & 50 & 40 \\
\hline 16 & 1.772 & 0.55 & 0.28 & 45 & 40 \\
\hline 3 & 1.773 & 0.55 & 0.05 & 45 & 40 \\
\hline 9 & 1.782 & 0.55 & 0.05 & 50 & 40 \\
\hline 2 & 1.783 & 0.55 & 0.05 & 45 & 20 \\
\hline
\end{tabular}




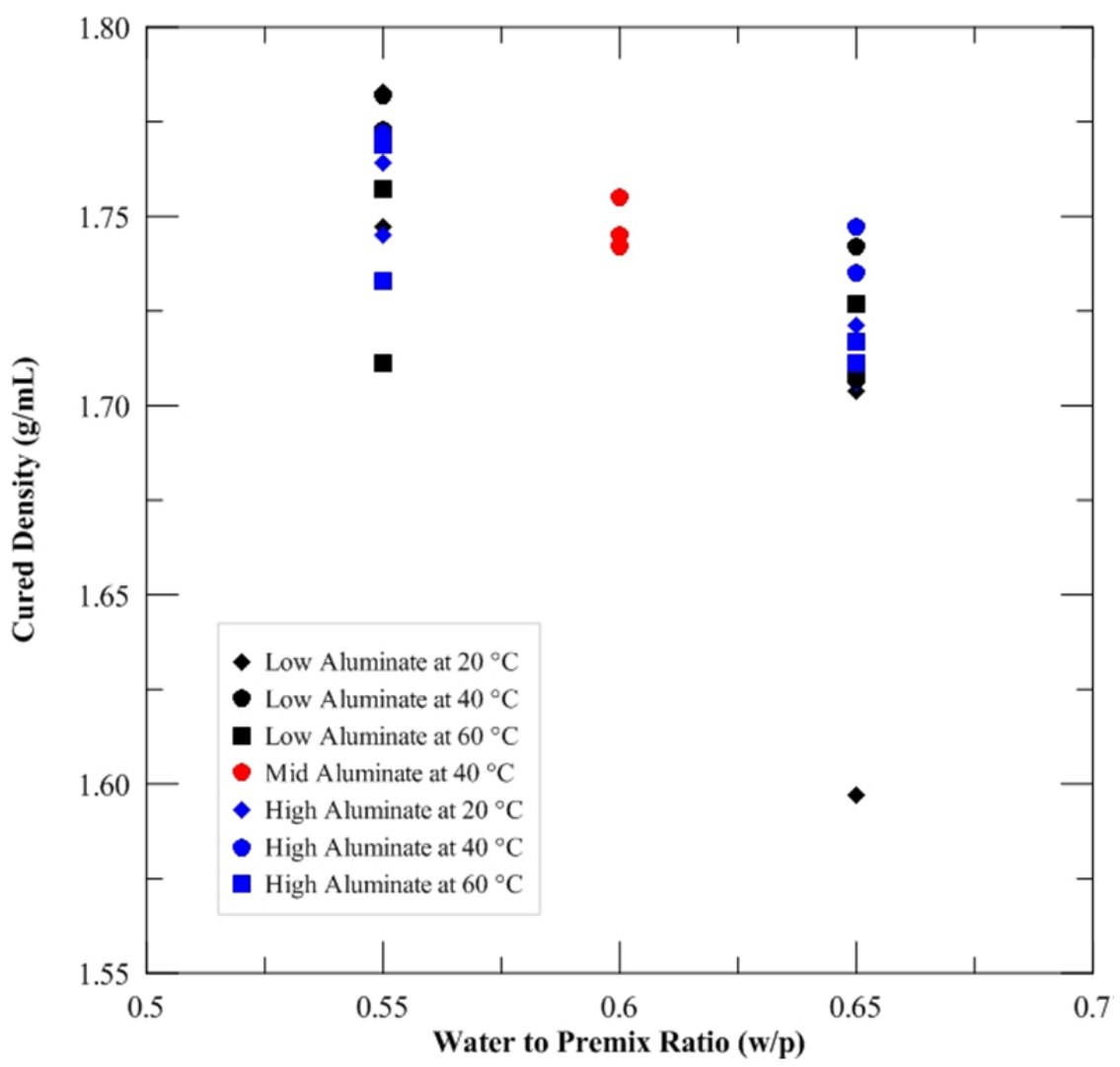

Figure 3-12. Cured density as a function of w/p for all mixes.

Figure 3-13 shows the variability of cured density of saltstone for the compositional and operational factors varied in this study. As shown by the values of the reference mixes (green dots), the measured cured density is consistent across all the mixes. Data from the previous study ${ }^{2}$ (gray X's) correspond well with the data from this study. The variability chart shows that fly ash content in the premix has an effect on the cured density of the grout. For grouts formulated with the low aluminate simulant and cured at $20{ }^{\circ} \mathrm{C}$, adding extra fly ash to the mix results in a decreased density of the grout. However, for all the other mixes, the opposite trend is observed. In general, increasing the percent fly ash in the premix leads to a denser saltstone. There is no distinct relationship between aluminate content of the salt solution and cured grout density. 


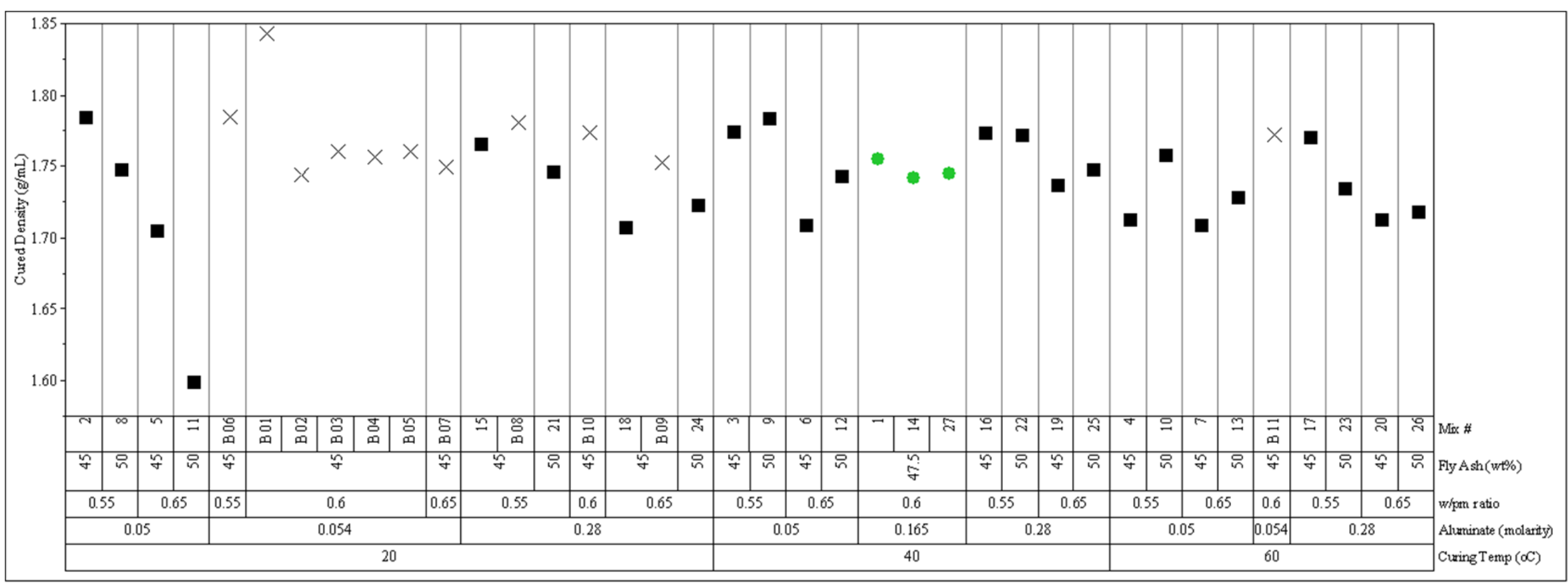

Figure 3-13. Variability chart for cured density as a function of operational and compositional variables. 
Stepwise linear regression was used to model the cured density values; the results are given in Table 3-10 and Figure 3-14. The $\mathrm{R}^{2}$ value is only $50.2 \%$, indicating little explanatory power in theis fitted model. The only statistically significant effects are for w/p and fly ash, with a tendency for density to decrease as either one of these variables increases.

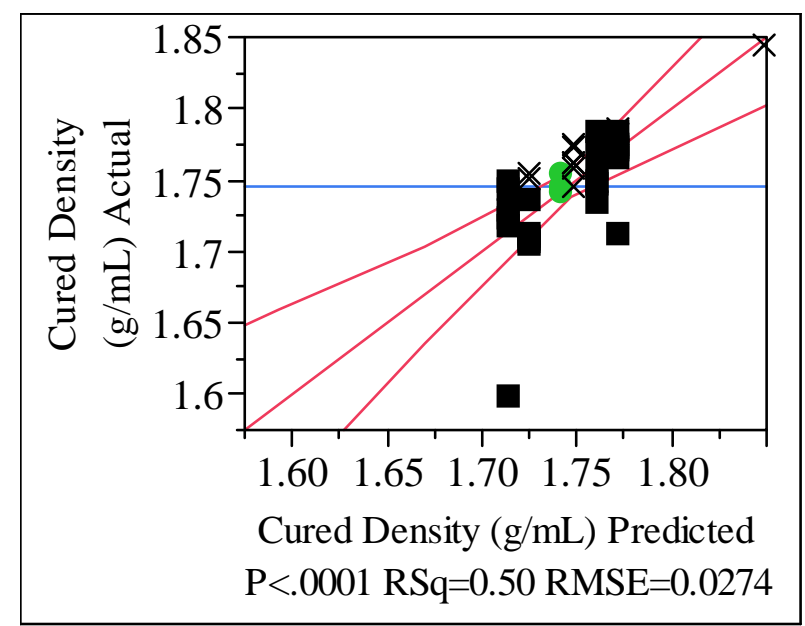

(a)

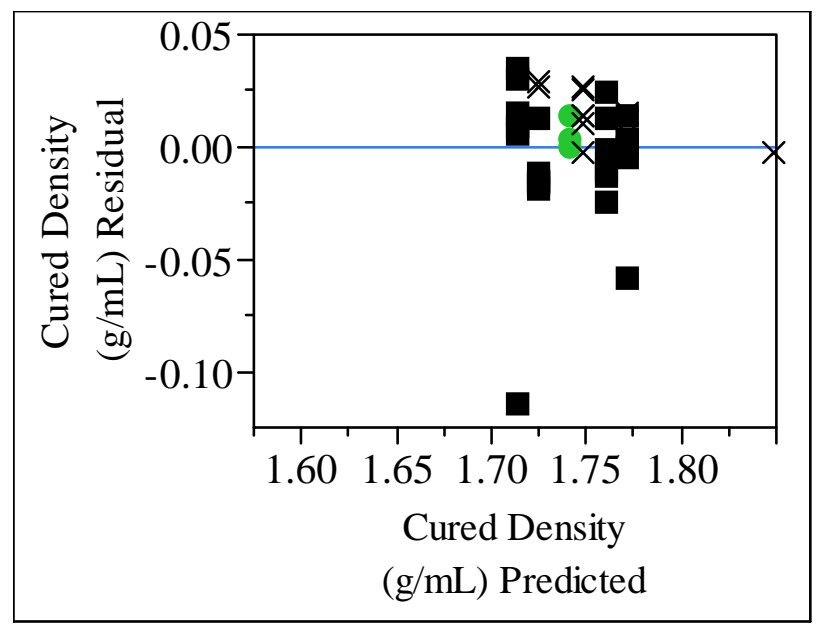

(b)

Figure 3-14. Response of cured density due to operational and compositional variables, (a) actual by predicted and (b) residual by predicted. 
Table 3-10. Summary of fit for the response of cured density values compared to the predicted model

\begin{tabular}{|c|c|c|c|c|}
\hline \multicolumn{2}{|c|}{ Summary of Fit } & & & \\
\hline R Square & 0.502 & & & \\
\hline R Square Adj & 0.941 & & & \\
\hline Root Mean Square Error & 0.473 & & & \\
\hline Mean of Response & 1.749 & & & \\
\hline Observations (or Sum Wgts) & 38 & & & \\
\hline \multicolumn{5}{|c|}{ Analysis of Variance } \\
\hline Source & DF & Sum of Squares & Mean Square & F Ratio \\
\hline Model & 2 & 0.02643638 & 0.013218 & 17.6220 \\
\hline Error & 35 & 0.02625334 & 0.000750 & Prob $>$ F \\
\hline C. Total & 37 & 0.05268972 & -- & $<.0001$ \\
\hline Source & DF & Sum of Squares & Mean Square & F Ratio \\
\hline Lack Of Fit & 4 & 0.00149514 & 0.000374 & 0.4680 \\
\hline Pure Error & 31 & 0.02475820 & 0.000799 & -- \\
\hline \multirow{2}{*}{ Total Error } & \multirow{2}{*}{35} & \multirow{2}{*}{0.02625334} & Prob $>$ F & 0.7587 \\
\hline & & & Max RSq & 0.5301 \\
\hline \multicolumn{5}{|c|}{ Parameter Estimates } \\
\hline Term & Estimate & Std Error & t Ratio & Prob $>|t|$ \\
\hline Intercept & 2.1244595 & 0.067427 & 31.51 & $<.0001$ \\
\hline w/p ratio & -0.462571 & 0.103516 & -4.47 & $<.0001$ \\
\hline Fly Ash (wt\%) & -0.002217 & 0.000567 & -3.91 & 0.0004 \\
\hline
\end{tabular}

\subsection{Correlation between Dynamic Young's Modulus and Hydraulic Conductivity}

Previous studies on the performance properties have indicated a relationship exists between the hydraulic conductivity and Young's modulus for saltstone., ${ }^{1,2,17}$ The limited data set analyzed in those studies indicated a relationship between the two performance properties. ${ }^{12,13,17}$ Incorporating data from a previous study ${ }^{13}$ with the data from this study indicates a quadratic relationship (Figure 3-15). The $\mathrm{R}^{2}$ value for this fit is $77.1 \%$.

There is a linear correlation these performance properties up to Young's modulus values of $7 \mathrm{GPa}$ and hydraulic conductivities of $1 \times 10 \mathrm{E}-9 \mathrm{~cm} / \mathrm{sec}$. At this point, that the data becomes more scattered and the data is not as well modeled. The constant-volume falling head method ${ }^{14}$ is known to have difficulty measuring samples with hydraulic conductivities values around $1 \mathrm{x} 10 \mathrm{E}-$ 9 to E-10 cm/sec or greater. This could account for the increased scatter in the data at higher Young's modulus values.

It appears that this model can be used to estimate the hydraulic conductivity of a sample based its Young's modulus for a limited range of values; however the entire data set cannot be well modeled. More data points would have to be included to further define the relationship between these performance properties for high Young's moduli and low hydraulic conductivities. Based on current and past data, Young's modulus is not a viable method to estimate the hydraulic conductivity of saltstone. 


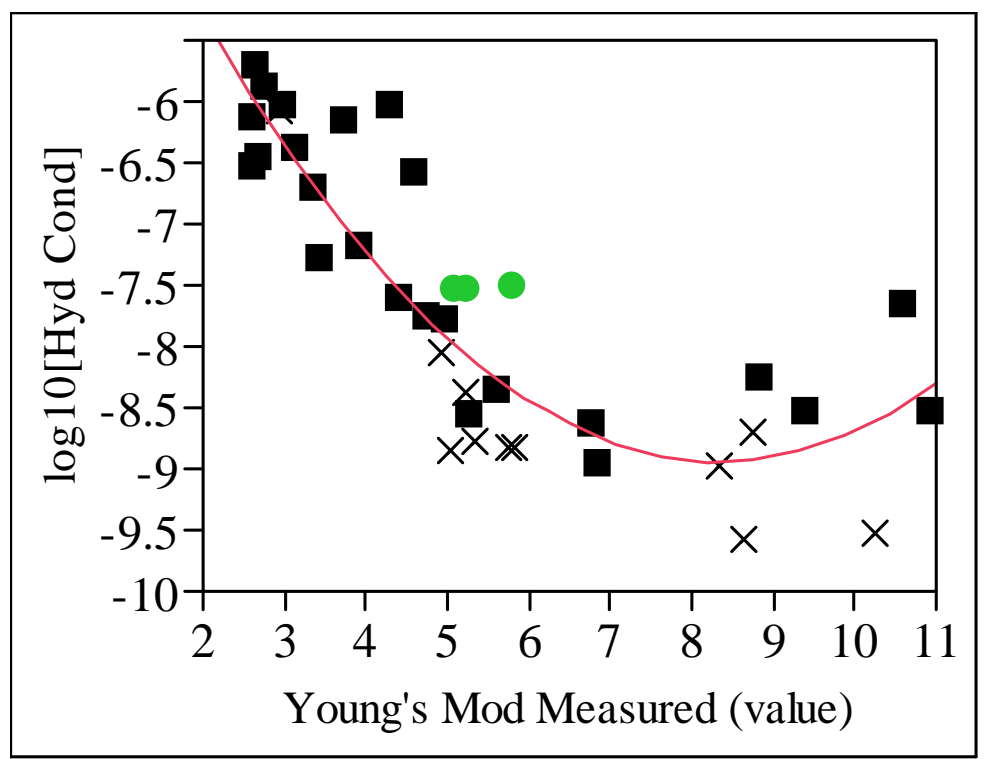

Figure 3-15. $\log _{10}$ of hydraulic conductivity as a function of Young's modulus showing a second degree polynomial line fit.

\subsection{Correlations of Performance Properties}

The effects of the compositional and operational factors on the performance properties of saltstone are complicated and interrelated. The data in Figure 3-16 and Table 3-11 show the correlations between saltstone performance properties. Section 3.6 discusses the inverse relationship between Young's modulus and hydraulic conductivity.

Table 3-11. Multivariate correlations between saltstone performance properties

\begin{tabular}{|l|c|c|c|c||}
\cline { 2 - 5 } \multicolumn{1}{c|}{} & $\begin{array}{c}\text { Young's Modulus } \\
\text { Measured (value) }\end{array}$ & $\begin{array}{c}\text { Porosity Measured } \\
\text { (value \%) }\end{array}$ & $\begin{array}{c}\text { Cured Density } \\
\text { (g/mL) }\end{array}$ & $\begin{array}{c}\log _{10} \\
\text { (Hyd Con) }\end{array}$ \\
\hline $\begin{array}{l}\text { Young's Mod } \\
\text { Measured (value) }\end{array}$ & 1.0000 & -0.4104 & 0.3199 & -0.7496 \\
\hline $\begin{array}{l}\text { Porosity Measured } \\
\text { (value \%) }\end{array}$ & -0.4104 & 1.0000 & -0.1802 & 0.1315 \\
\hline $\begin{array}{l}\text { Cured Density } \\
\text { (g/mL) }\end{array}$ & 0.3199 & -0.1802 & 1.0000 & -0.3393 \\
\hline $\log _{10}$ (Hyd Con) & -0.7496 & 0.1315 & -0.3393 & 1.0000 \\
\hline
\end{tabular}




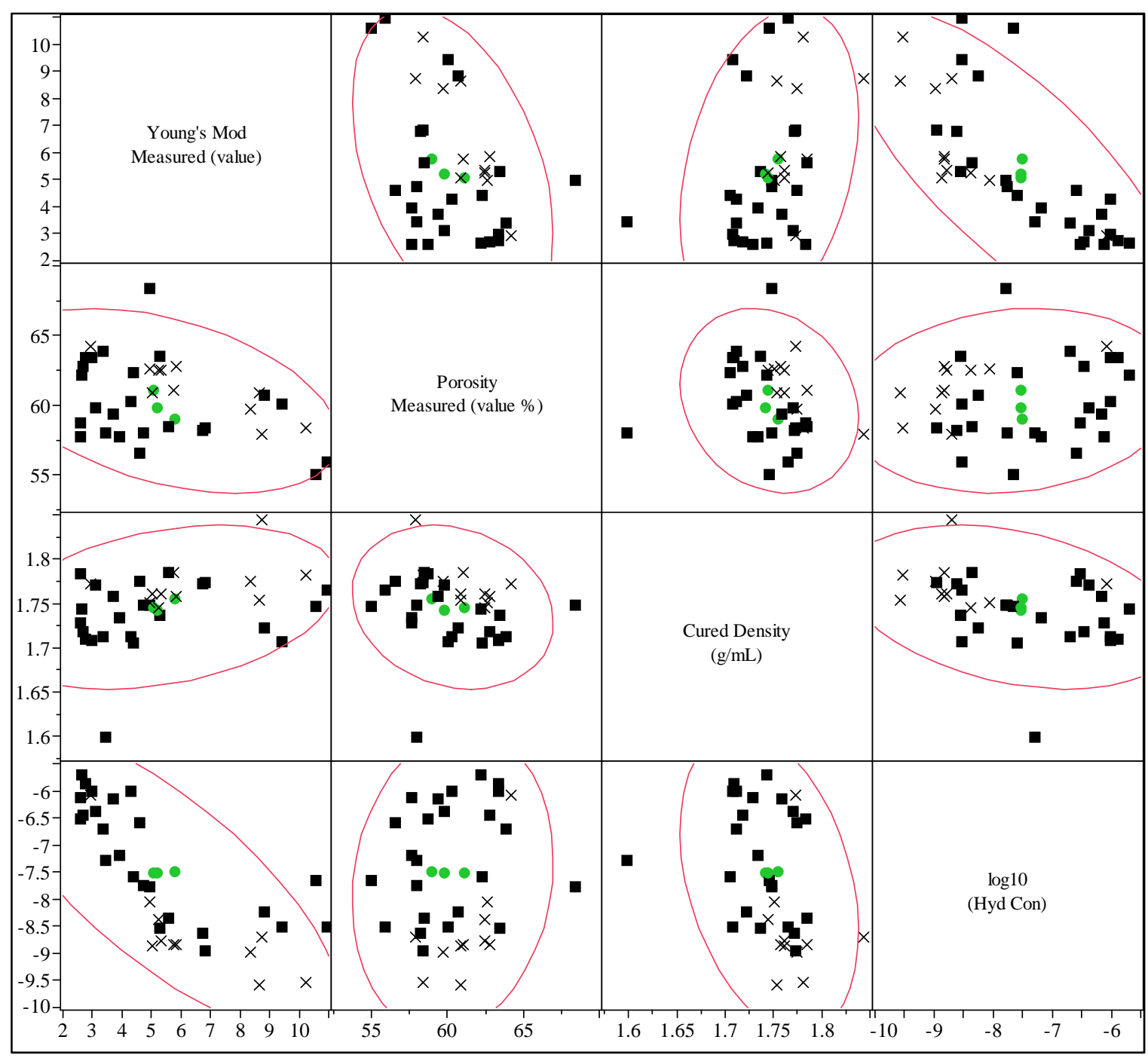

Figure 3-16. Scatter plot matrix showing the correlation between performance properties.

The inverse correlation between Young's modulus and porosity is due to decreased strength as the porosity of the grout is increased (Table 3-11, Equation 2). However, it has been determined that the $\mathrm{E}$ values obtained for this equation are dependent on the relative humidity (RH) at which the sample is conditioned. ${ }^{19}$ If the sample is cured at a low RH, the pores dry out causing shrinkage and decreased strength. Curing at high temperature under a high RH keeps the pores saturated which leads to an overall higher strength. ${ }^{19}$

$$
E=E_{0}\left(1-p_{C}\right)^{3}
$$

Where $E$ is the calculated Young's modulus, $E_{0}$ is the Young's modulus extrapolated to zero porosity, and $p_{C}$ is the capillary porosity.

Cure temperature also has an effect on the relationship between Young's modulus and porosity. It has been discussed that high temperature curing affects the microstructural development of grout. This is especially true of grouts cured at elevated temperature and subsequently hydrated further at ambient temperature. The rapid hydration at higher temperatures leads to encapsulation of 
porous cementitious materials by a layer of dense hydrated product, causing an overall increase in grout porosity. ${ }^{19}$ In addition, the mass loss of the sample as a result of curing at elevated temperatures would affect the cured density and therefore the grout porosity, since the cured density is used to calculate the grout porosity. For the calculation of porosity, as the grout density decreases, the porosity also decreases.

The positive correlation between hydraulic conductivity and porosity is expected. The size and continuity of the pores control the hydraulic conductivity of grout, but there is no direct proportionality between the two. ${ }^{15}$ At some point, the porosity will be so low that decreasing it further will result in only a slight decrease in the hydraulic conductivity. The water to premix is a key factor in the pore development and interconnectedness. The hydraulic conductivity will also have an inverse relationship with the cured density of the grout. The more compact the grout with minimal voids, the lower the hydraulic conductivity.

Higher density grouts will have higher Young's moduli. This is due to lower void spaces and lower porosity in the grout resulting in a higher strength material. This is also the reason for the inverse relationship between cured density and porosity.

\subsection{Time Temperature Performance}

Young's modulus of the samples cured under actual vault temperature profiles was measured at 3 , 4, 5, 6, 10, 17 and 24 days of curing. The temperature profiles used are shown in Figure 2-1. Young's modulus data is shown in Figure 3-17.

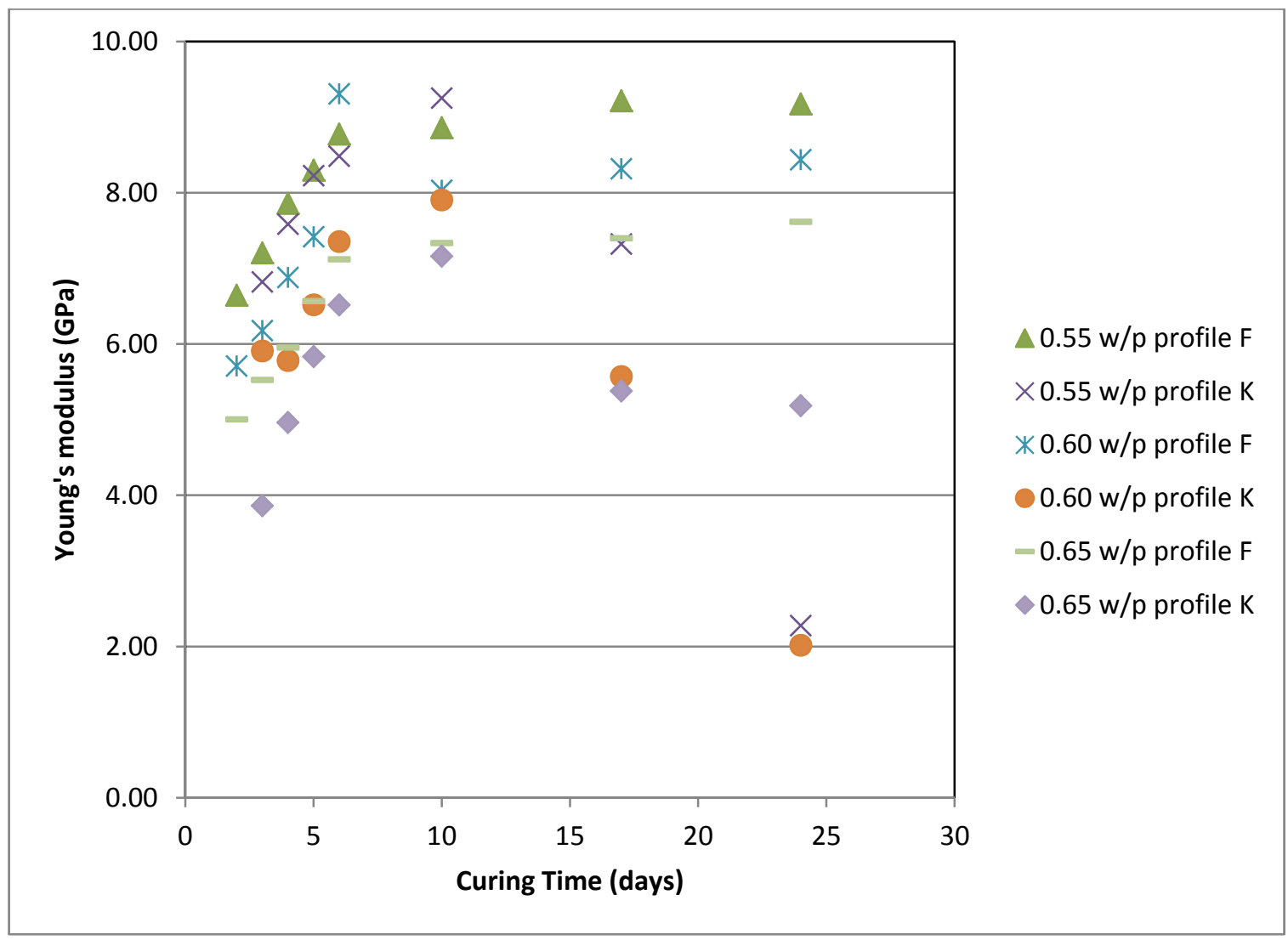

Figure 3-17. Young's modulus as a function of curing time at varying temperature profiles 
At curing times up to 10 days, performance is driven by w/p ratio. Higher w/p ratio grouts generally have lower Young's moduli, as seen earlier in this study and in previous work. At longer curing times, the performance of the grouts cured at higher temperatures falls off. Physical examination of the high cure temperature samples shows visible surface cracking after 10 days. Figure 3-18 shows a 50x magnification of a sample cured for 24 days under the higher temperature profile. Numerous cracks are visible in this image that are indicative of drying.

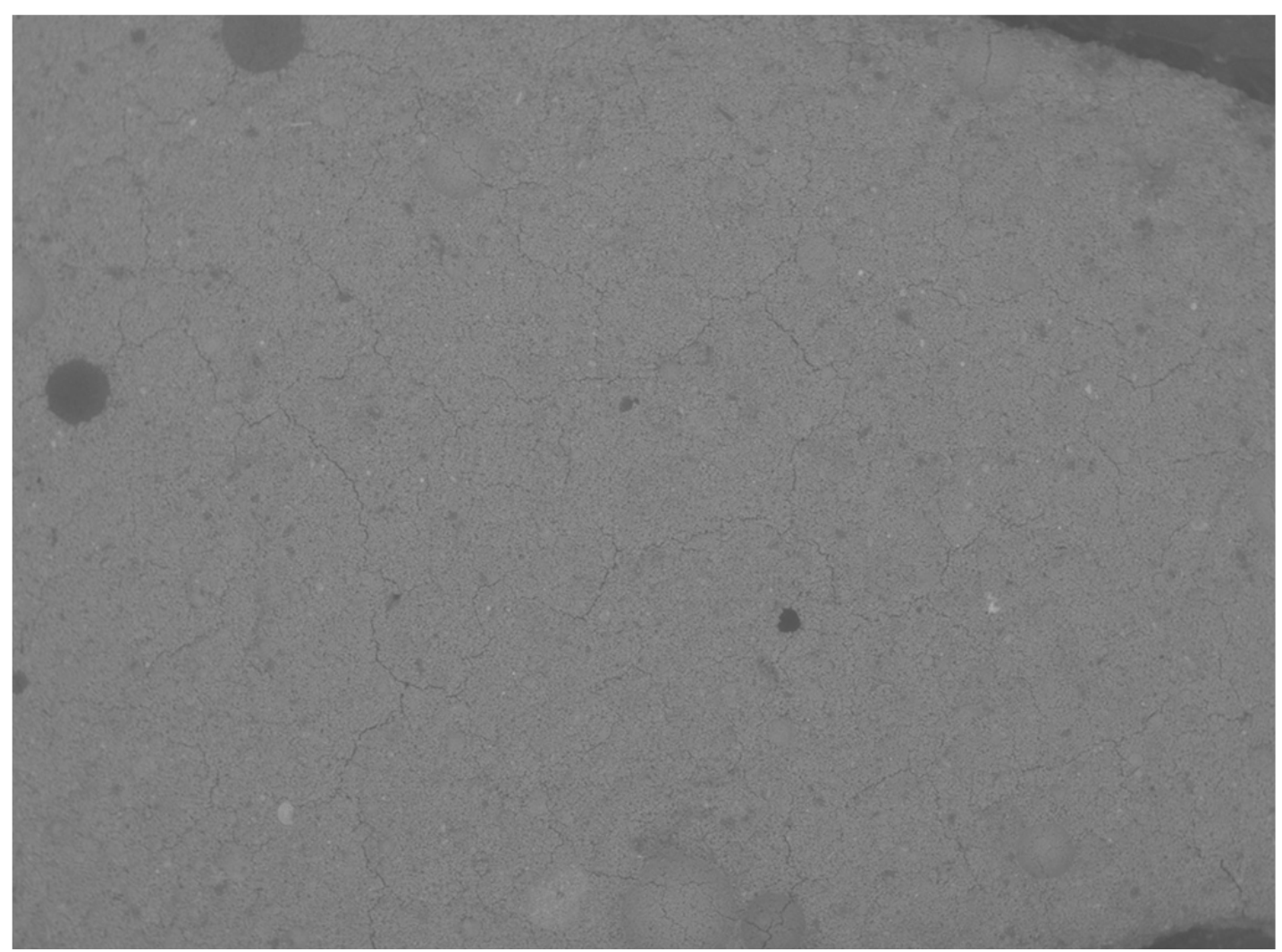

Figure 3-18. SEM image of grout cured for 24 days at high temperature

The mass losses of the individual samples are shown in Table 3-12. This data further illustrates the drying that occurred during curing. Mass loss on the 24 day samples is as much as 4 times greater for the higher temperature profile as compared to the lower profile. This dehydration contributes to the decreasing Young's modulus in the higher temperature samples. It is unclear whether the negative performance is partially due to the curing temperature or entirely because of damage caused to the samples by drying. 
Table 3-12 Mass loss in Time-Temperature samples

\begin{tabular}{|c|c|c|c|c|c|}
\hline $\begin{array}{c}\text { w/p } \\
\text { ratio }\end{array}$ & $\begin{array}{c}\text { cure time } \\
\text { (days) } \\
\text { Cell F Profile }\end{array}$ & $\begin{array}{c}\text { mass loss } \\
\mathbf{( \% )}\end{array}$ & $\begin{array}{c}\text { w/p } \\
\text { ratio }\end{array}$ & $\begin{array}{c}\text { cure time } \\
\text { (days) } \\
\text { Profile 2 }\end{array}$ & $\begin{array}{c}\text { mass loss } \\
\mathbf{( \% )}\end{array}$ \\
\hline \hline 0.55 & 2 & -0.02 & 0.55 & 2 & N/A \\
\hline 0.55 & 3 & 0.04 & 0.55 & 3 & -0.01 \\
\hline 0.55 & 4 & -0.01 & 0.55 & 4 & 0.00 \\
\hline 0.55 & 5 & 0.00 & 0.55 & 5 & N/A \\
\hline 0.55 & 6 & 0.02 & 0.55 & 6 & 0.07 \\
\hline 0.55 & 10 & 0.09 & 0.55 & 10 & 0.32 \\
\hline 0.55 & 17 & 0.11 & 0.55 & 17 & 0.61 \\
\hline 0.55 & 24 & 0.14 & 0.55 & 24 & 0.59 \\
\hline 0.6 & 2 & -0.02 & 0.6 & 2 & N/A \\
\hline 0.6 & 3 & -0.03 & 0.6 & 3 & -0.01 \\
\hline 0.6 & 4 & 0.01 & 0.6 & 4 & 0.01 \\
\hline 0.6 & 5 & 0.00 & 0.6 & 5 & N/A \\
\hline 0.6 & 6 & 0.02 & 0.6 & 6 & 0.03 \\
\hline 0.6 & 10 & 0.03 & 0.6 & 10 & 0.16 \\
\hline 0.6 & 17 & 0.08 & 0.6 & 17 & 0.43 \\
\hline 0.6 & 24 & 0.07 & 0.6 & 24 & 0.84 \\
\hline 0.65 & 2 & -0.01 & 0.65 & 2 & N/A \\
\hline 0.65 & 3 & -0.02 & 0.65 & 3 & -0.01 \\
\hline 0.65 & 4 & 0.01 & 0.65 & 4 & 0.00 \\
\hline 0.65 & 5 & -0.01 & 0.65 & 5 & N/A \\
\hline 0.65 & 6 & 0.04 & 0.65 & 6 & 0.05 \\
\hline 0.65 & 10 & 0.10 & 0.65 & 10 & 0.22 \\
\hline 0.65 & 17 & 0.12 & 0.65 & 17 & 0.56 \\
\hline 0.65 & 24 & 0.19 & 0.65 & 24 & 0.89 \\
\hline
\end{tabular}




\subsection{Conclusions and Recommendations}

A statistically designed set of mixes was developed to determine key process and compositional factors that affect the performance properties of saltstone. A total of 27 mixes were batched and tested. There are eight baseline mixes that contain high and low concentrations of aluminate, varying water to premix (w/p) ratios, and varying fly ash content in the premix. Each of the eight mixes was cured at 20, 40 , and $60{ }^{\circ} \mathrm{C}$. Three additional reference mixes were batched at the beginning, middle and end of testing to measure reproducibility.

The fresh properties of the grout mixes were measured to ensure the product can be processed through the facility and sent to the vault. The mixes had no bleed after one day except for mixes 18 and 24. The surface of these two samples was still wet after one day but there was not enough bleed to measure. In addition to no bleed, all of the grouts gelled within 60 minutes, which is within the processing guidelines used to support the Saltstone Production Facility.

The results of varying the operational and compositional factors over the ranges investigated on the performance properties of saltstone are:

- The Young's modulus is inversely affected by the curing temperature of the grout.

- The aluminate content of the salt solution increases the Young's modulus of the saltstone for samples cured at 20 and $40^{\circ} \mathrm{C}$.

- All grouts cured at $60{ }^{\circ} \mathrm{C}$ have low Young's moduli compared to the same grout cured at room temperature.

- Changing the composition (aluminate molarity, fly ash concentration, and w/p) did not improve the performance properties of saltstone cured at $60^{\circ} \mathrm{C}$.

- The fly ash content in the premix had no discernible effect on the Young's modulus.

- The water to premix ratio does not affect the Young's modulus.

- Grouts made with the high aluminate salt solution have lower hydraulic conductivities than those made with the low aluminate simulant.

- Higher curing temperatures result in higher values of hydraulic conductivity.

- In general, increasing the water to premix ratio and the fly ash content will increase the hydraulic conductivity, specifically for grouts cured at low temperatures.

- The porosity and cured density of the saltstone are primarily a factor of the water to premix ratio of the grout formulation.

The correlation between hydraulic conductivity and Young's modulus investigated in previous studies was evaluated further in this report. The current data, as well as data from previous studies, were fitted by a second degree polynomial function with a $77.1 \%$ R-squared value. This model can be used to estimate the hydraulic conductivity of a sample based on its Young's modulus for a limited range (E values up to $7 \mathrm{GPa}$ ). More data points would have to be included to further define the relationship between these performance properties for high Young's moduli and low hydraulic conductivities. Based on current and past data, Young's modulus is not a viable method to estimate the hydraulic conductivity of saltstone.

Saltstone has a complicated microstructure that is affected by the composition of the salt solution, the dry feed mixture composition, and the conditions under which it cures. The performance properties investigated are interrelated, which can make it difficult to determine individual relationships between various factors. Porosity is a large factor in determining both the Young's modulus and the hydraulic conductivity of the samples. Although the cured density is a straightforward measurement, it is not a significant performance property that needs further 
investigation. The porosity measurement provides similar and more meaningful data in relation to other performance properties.

Based on the results of this study, the aluminate content of the salt solution does have an effect on the Young's modulus and the hydraulic conductivity and its effects should continue to be investigated. However, a new projection of aluminate content in the salt solution waste should be used since projections can change with revisions of the planning document ${ }^{8}$. Samples should be analyzed by scanning electron microscopy (SEM) and x-ray diffraction to determine the change in microstructure and phases present in the grout as a function of aluminate content. The variability of fly ash in the premix did not prove to be a contributing factor that effects the performance properties of saltstone and doesn't need to be included in future studies unless significant deviations from the baseline mix are proposed.

The water to premix ratio has a significant effect on the performance properties of interest and the effects of varying this parameter need further investigation. It is recommended that smaller ranges of $\mathrm{w} / \mathrm{p}$ are investigated in order to provide data that is more relevant to the saltstone being placed in the vaults.

An additional part of this study includes curing selected samples under temperatures recorded in the SDF. The cure temperatures used in this study are representative of selected temperatures measured in the SDF vaults and, it is obvious that curing saltstone at high temperatures has a negative effect on the performance properties. However, the grout in the SDF vaults does not cure at a single temperature, rather it is exposed to a variable and gradually increasing temperature profile after it is placed. Some samples were cured under such temperature profiles and tested to determine the effect of a lower starting curing temperature followed by a higher ending temperature. After 10 days of curing, samples that reached a maximum of $55^{\circ} \mathrm{C}$ outperformed samples that were cured at $80^{\circ} \mathrm{C}$ in terms of Young's modulus. However, drying of the samples that were cured at higher temperatures is evident. It is recommended that in addition to curing under vault temperature profiles, samples be cured at high relative humidities in order to maintain saturated grout. It is unclear if the deleterious effects of curing at high temperatures is solely due to the drying of the samples or if there are other effects of curing at elevated temperatures. Curing future samples at various relative humidities will provide further insight into the performance properties of saltstone. 


\subsection{References}

1. Harbour, J.R., Edwards, T.B., and Williams, V.J., "Key Factors that Influence the Performance Properties of ARP/MCU Saltstone Mixes," Savannah River National Laboratory, SRNL-STI-2009-00546, September 2009.

2. Dixon, K.L., Harbour, J.R., and Phifer, M.A., "Hydraulic and Physical Properties of Saltstone Grout," Savannah River National Laboratory, SRNL-STI-2009-00419, Revision 0, May 2010.

3. "Performance Assessment for the Saltstone Disposal Facility at the Savannah River Site," Savannah River Remediation Cosure \& Waste Disposal Authority, SRR-CWDA-200900017, October 2009.

4. Harbour, J.R., Edwards, T.B., and Williams, V.J., "Impact of Time/Temperature Curing Conditions and Aluminate Concentration on Saltstone Properties," Savannah River National Laboratory, SRNL-STI-2009-00184, Rev. 0, 2009.

5. Harbour, J.R. and Edwards, T.B., "Measurement of the Hydraulic Conductivity and Young's Modulus for ARP/MCU Mixes as a Function of Key Operational/Compositional Factors," Savannah River National Laboratory, SRNL-RP-2010-00852, April 2010.

6. JMP, SAS Institute, Inc., Cary, NC, 1989 - 2008.

7. Harbour, J.R. and Williams, V.J., "Saltstone Performance Indicator - Dynamic Young's Modulus," Savannah River National Laboratory, SRNL-STI-2008-00488, Revision 0, December 2008.

8. Chew, D.P. and Hamm, B.A., "Liquid Waste System Plan," Savannah River Remediation, SRR-LWP-2009-00001 Revision 16, December 6, 2010.

9. $\quad$ "Standard Test Methods for Time of Setting of Hydraulic Cement by Vicat Needle," ASTM International, ASTM C 191 -08.

10. "Standard Test Method for Fundamental Transverse, Longitudinal, and Torsional Resonant Frequencies of Concrete Specimens," ASTM International, ASTM C 215 - 08.

11. Mindess, S. and Young, J.F., Concrete. Prentice-Hall, 1981.

12. Harbour, J.R., Williams, V.J., Edwards, T.B., Eibling, R.E., et al., "Saltstone Variability Study - Measurement of Porosity," Savannah River National Laboratory, WSRC-STI2007-00352, Revision 0, July 2007.

13. Dixon, K.L., "Moisture Retention Properties of High temperature Cure ARP/MCU Saltstone Grout," Savannah River National Laboratory, SRNL-STI-2011-00661, October 2011. 
14. "Standard Test Methods for Measurement of Hydraulic Conductivity of Saturated Porous Materials Using a Flexible Wall Permeameter," ASTM International, ASTM D 5084-03 (Method F).

15. Mehta, P.K. and Monteiro, P.J.M., Concrete: Microstructure, Properties, and Materials, Third ed. McGraw-Hill.

16. Harbour, J.R., Edwards, T.B., Williams, V.J., Scherer, G.W., et al., "Permeability of Saltstone - Measurement by Beam Bending," Washington Savannah River Company, WSRC-TR-2007-00437, 2007.

17. Harbour, J.R. and Williams, M.F., "Impact of Curing Temperature on the Saturated Liquid Permeability of Saltstone," Savannah River National Laboratory, SRNL-STI2010-00745, Revision 0, February 2011.

18. Shackelford, J.F., Introduction to Materials Science for Engineers, Fifth ed. Prentice Hall, 2000.

19. Taylor, H.F.W., Cement Chemistry, Second ed. Thomas Telford, 2004. 
SRNL-STI-2011-00665

Revision 0

\section{A. APPENDIX A}


Table A-1. Batch formulations for samples from report SRNL-STI-2009-00419.

\begin{tabular}{||c|c|c|c|c||}
\hline $\begin{array}{c}\text { Mix } \\
\text { Number }\end{array}$ & $\begin{array}{c}\text { Aluminate } \\
\text { Molarity }\end{array}$ & w/p & $\begin{array}{c}\text { Fly Ash } \\
(\mathbf{\%})\end{array}$ & $\begin{array}{c}\text { Curing } \\
\left.\text { Temp ( }{ }^{\circ} \mathbf{C}\right)\end{array}$ \\
\hline B01 & 0.054 & 0.6 & 0 & 20 \\
\hline B02 & 0.054 & 0.6 & 45 & 20 \\
\hline B03 & 0.054 & 0.6 & 45 & 20 \\
\hline B04 & 0.054 & 0.6 & 45 & 20 \\
\hline B05 & 0.054 & 0.6 & 45 & 20 \\
\hline B06 & 0.054 & 0.55 & 45 & 20 \\
\hline B07 & 0.054 & 0.65 & 45 & 20 \\
\hline B08 & 0.28 & 0.55 & 45 & 20 \\
\hline B09 & 0.28 & 0.65 & 45 & 20 \\
\hline B10 & 0.28 & 0.6 & 45 & 20 \\
\hline B11 & 0.054 & 0.6 & 45 & 60 \\
\hline
\end{tabular}

Table A-2. Performance properties of mixes batched in SRNL-STI-2009-00419

\begin{tabular}{|c|c|c|c|c||}
\hline $\begin{array}{c}\text { Mix } \\
\text { Number }\end{array}$ & E (GPa) & Porosity (\%) & $\begin{array}{c}\text { Cured } \\
\text { Density } \\
\mathbf{( g / m L ) ~}^{\mathbf{a}}\end{array}$ & $\begin{array}{c}\text { Hydraulic } \\
\text { Conductivity (cm/s) }\end{array}$ \\
\hline \hline B01 & 8.7 & 57.8 & 1.8427 & $1.90 \mathrm{E}-09$ \\
\hline B02 & 5.2 & 62.4 & 1.7435 & $4.00 \mathrm{E}-09$ \\
\hline B03 & 5.3 & 62.4 & 1.7597 & $1.60 \mathrm{E}-09$ \\
\hline B04 & 5.8 & 62.7 & 1.7558 & $1.40 \mathrm{E}-09$ \\
\hline B05 & 5 & 60.8 & 1.7595 & $1.30 \mathrm{E}-09$ \\
\hline B06 & 5.7 & 61 & 1.7837 & $1.40 \mathrm{E}-09$ \\
\hline B07 & 4.9 & 62.5 & 1.749 & $8.40 \mathrm{E}-09$ \\
\hline B08 & 10.2 & 58.3 & 1.7801 & $2.80 \mathrm{E}-10$ \\
\hline B09 & 8.6 & 60.8 & 1.7522 & $2.50 \mathrm{E}-10$ \\
\hline B10 & 8.3 & 59.6 & 1.7728 & $1.00 \mathrm{E}-09$ \\
\hline B11 & 2.9 & 64.1 & 1.7712 & $8.00 \mathrm{E}-07$ \\
\hline
\end{tabular}

\footnotetext{
${ }^{a}$ The cured density is not reported in the referenced document, but the data was taken as part of recording other cured properties during the evolution of this study. The data is recorded in the spreadsheet that calculates the Young's modulus for each sample.
} 


\section{Distribution:}

\begin{tabular}{|c|c|c|}
\hline М. & Almond & 43A \\
\hline A. B. & Barnes & 999-W \\
\hline H. H. & Burns & 773-41A \\
\hline r. W. & Coffield & 705-1C \\
\hline A. D. & Cozzi & 999-W \\
\hline A. & Crowley & $773-43 A$ \\
\hline B. & Edwards & 999-W \\
\hline D. & Fink & 773-A \\
\hline S. P. & Flach & $773-42 A$ \\
\hline 3. J. & Giddings & 786-5A \\
\hline I. C. & Griffin & 773-A \\
\hline C. C. & Herman & 999-W \\
\hline D. I. & Kaplan & 773-43A \\
\hline C. A. & Langton & 773-43A \\
\hline J. N. & Leita & $704-Z$ \\
\hline S. L. & Marra & 773-A \\
\hline J. E. & Occhipinti & 704-S \\
\hline F. M. & Pennebaker & $773-42 A$ \\
\hline M. A. & Phifer & $773-42 A$ \\
\hline B. R. & Pickenheim & 999-W \\
\hline M. M. & Reigel & 999-W \\
\hline K. H. & Rosenberger & $705-1 C$ \\
\hline R. E. & Sheppard & $705-1 C$ \\
\hline D. C. & Sherburne & $704-S$ \\
\hline F. M. & Smith & $705-1 \mathrm{C}$ \\
\hline A. V. & Staub & $704-27 S$ \\
\hline $\mathrm{I} P$ & Tihey & 704-Z \\
\hline
\end{tabular}

